1 Hydrogen isotope fractionation of leaf wax $n$-alkanes in southern

2 African soils

3 Nicole Herrmann ${ }^{a^{*}}$, Arnoud Boom ${ }^{b}$, Andrew S. Carr ${ }^{b}$, Brian M. Chase ${ }^{c}$, Adam G.

4 West $^{d}$, Matthias Zabel ${ }^{a}$, Enno Schefuß ${ }^{a}$

5 a MARUM - Center for Marine Environmental Sciences, University of Bremen, Leobener

6 Straße, Bremen, Germany

7 b Department of Geography, University of Leicester, University Road, Leicester LE1

$87 R H$, United Kingdom

$9{ }^{c}$ Centre National de Recherche Scientifique, UMR 5554, Institute des Sciences de

10 l'Evolution de Montpellier, Département Paléoenvironnements, Université Montpellier,

11 Bat.22, CC061, Place Eugène Bataillon, 34095, Montpellier, Cedex 5, France

12 d Department of Biological Sciences, University of Cape Town, Rondebosch 7701,

13 Western Cape, South Africa

$14{ }^{*}$ Corresponding author.

15 E mail: nicole.herrmann@uni-hamburg.de (Nicole Herrmann).

\title{
16 ABSTRACT
}

17 The hydrogen isotope composition of plant leaf wax $\left(\delta \mathrm{D}_{\mathrm{wax}}\right)$ has been found to record

18 the isotope composition of precipitation $\left(\delta D_{p}\right)$. Hence, $\delta D_{\text {wax }}$ is increasingly used for

19 palaeohydrological reconstruction. $\delta D_{\text {wax }}$ is, however, also affected by secondary factors,

20 such as vegetation type, evapotranspiration and environmental conditions, complicating

21 its direct application as a quantitative palaeohydrological proxy. Here, we present $\delta D_{\text {wax }}$

22 data from soils along vegetation gradients and climatic transects in southern Africa to

${ }^{1}$ present address: Institute for Geology, University of Hamburg, Bundesstraße 55, Hamburg, Germany 
23 investigate the impact of different environmental factors on $\delta D_{\text {wax }}$. We found that $\delta D_{\text {wax }}$

24 correlated significantly with annual $\delta D_{p}$ (obtained from the interpolated Online Isotopes

25 in Precipitation Calculator data set) throughout the eastern and central South Africa,

26 where the majority of the mean annual precipitation falls during the summer. We found

27 evidence for the effect of evapotranspiration on $\delta D_{\text {wax }}$, while vegetation change was of

28 minor importance. In contrast, we found that $\delta D_{\text {wax }}$ did not correlate with annual $\delta D_{p}$ in

29 western and southwestern South Africa, where most of the annual precipitation falls

30 during winter. Wide microclimatic variability in this topographical variable region,

31 including distinct vegetation communities and high vegetation diversity between biomes

32 as well as a potential influence of summer rain in some locals, likely compromised

33 identification of a clear relationship between $\delta D_{\text {wax }}$ and $\delta D_{p}$ in this region. Our findings

34 have implications for palaeoenvironmental investigations using $\delta D_{\operatorname{wax}}$ in southern Africa.

35 In the summer rain dominated eastern and central region, $\delta D_{\text {wax }}$ should serve well as a

36 qualitative palaeohydrological recorder. In contrast, the processes influencing $\delta D_{\text {wax }}$ in

37 the winter rain dominated western and southwestern South Africa remain unclear and

38 pending further analyses potentially constrain its use as palaeohydrological proxy in this 39 region.

40 Keywords: Compound-specific hydrogen isotopes; Southern Africa; Soils; Plant wax;

$41 \quad n$-Alkanes

42 1. Introduction

43 Long chain $n$-alkanes of plant leaf wax, and their compound-specific stable hydrogen

44 isotope composition ( $\delta D_{\text {wax }}$ ) are widely used as a palaeoenvironmental proxy, providing 
45 insights into past hydrological conditions (e.g. Schefuß et al., 2005; Seki et al., 2009;

46 Niedermeyer et al., 2010; Collins et al., 2013; Kuechler et al., 2013). They are stable

47 over geological time scales (Schimmelmann et al., 2006; Eglinton and Eglinton, 2008)

48 and $\delta D_{\text {wax }}$ in lake surface sediments and soils has been shown to correlate with $\delta D$ of

49 local precipitation ( $\delta \mathrm{D}_{\mathrm{p}}$; Sachse et al., 2004; Rao et al., 2009; Polissar and Freeman,

50 2010; Luo et al., 2011; Garcin et al., 2012; Schwab et al., 2015; Tuthorn et al., 2015).

51 However, $\delta D_{\text {wax }}$ has also been shown to be influenced by other factors, such as

52 evapotranspiration or plant growth form, which may bias its signal (e.g. Hou et al., 2008;

53 Feakins and Sessions, 2010a; Seki et al., 2010; Douglas et al., 2012; Kahmen et al.,

54 2013b; Berke et al., 2015). To reliably reconstruct hydrological changes in specific

55 settings it is thus essential to understand the factors affecting $\delta D_{\text {wax }}$ in specific 56 environments.

57 The primary factor controlling $\delta D_{\text {wax }}$ is the hydrogen isotope composition of

58 precipitation which depends on various environmental processes. These include the 59 intensity of precipitation (amount effect), the distance that moisture has travelled over a 60 continental landmass (continental effect), the altitude effect, condensation temperature 61 (temperature effect) and the global ice volume (ice effect) (Dansgaard, 1964; Gat, 1996;

62 Araguás-Araguás et al., 2000). In detail, the amount effect describes the decrease in $63 \delta D_{p}$ with increasing rainfall amount/intensity and is most pronounced in the tropics and 64 mid-latitudes during the rainy season(Dansgaard, 1964; Rozanski et al., 1993; Worden 65 et al., 2007; Risi et al., 2008). Decreasing $\delta D_{p}$ is also caused by air masses moving over 66 land away from their oceanic source due to preferential removal of isotopically enriched 67 precipitation during rainout and isotopically depleted residual. The same process 
68 decreases $\delta D_{p}$ during orographic uplift of atmospheric moisture, known as the altitude

69 effect (Dansgaard, 1964; Rozanski et al., 1993). With decreasing temperature, the

70 atmosphere can store less moisture, resulting in greater effective rainfall and therefore

71 greater depletion of $\delta D_{p}$ (temperature effect), which becomes a more important effect at

72 mid-to high latitudes (Dansgaard, 1964; Rozanski et al., 1993). Additionally, over longer

73 time-scales the global ice volume affects the isotope composition of mean ocean surface

74 water (Dansgaard, 1964).

75 As soil water and precipitation are the main sources of plant water, their isotopic

76 signature is taken up by plants in their stem water (e.g. Flanagan and Ehleringer, 1991;

77 Gat, 1996). An additional factor that may then alter leaf water $\delta D$ is $D$ enrichment due to

78 evapotranspiration, which is most pronounced in arid regions (e.g. Krull et al., 2006; Liu

79 et al., 2006; Kahmen et al., 2013a). Furthermore, apparent hydrogen isotope

80 fractionation (i.e. the difference between $\delta D_{p}$ and $\delta D_{\text {wax }}$ ) has been shown to vary with

81 vegetation type (e.g. grasses, shrubs; Kahmen et al., 2013b), photosynthetic pathway

82 (Liu and Yang, 2008; Feakins and Sessions, 2010b; Gamarra et al., 2016), leaf shape

83 (Gao et al., 2015) and water use efficiency (Hou et al., 2007a; Liu and Yang, 2008).

84 Some studies show large differences in hydrogen isotope fractionation between source 85 water and leaf wax, with substantially smaller apparent fractionation reported in arid vs.

86 humid climates (e.g Feakins and Sessions, 2010a; Polissar and Freeman, 2010; Smith

87 and Freeman, 2006). Additionally, CAM plants, common in semi-arid and arid 88 environments (Ting, 1985), have been reported to exhibit smaller apparent fractionation 89 than $\mathrm{C}_{3}$ and $\mathrm{C}_{4}$ plants (Feakins and Sessions, 2010b). As apparent fractionation, mostly 90 of $C_{3}$ vs. $C_{4}$ plants, is often used for palaeohydrological reconstruction, the 
91 environmental controls on apparent fractionation in semi-arid to arid regions is of

92 substantial interest

93

While many studies of leaf wax focus on plants, either in natural environments or

94 greenhouse experiments (e.g. Bi et al., 2005; Sachse et al., 2006; Smith and Freeman, 95 2006; Hou et al., 2007a; Liu and Yang, 2008; Feakins and Sessions, 2010b; Mclnerney 96 et al., 2011; Gao et al., 2014, 2015; Feakins et al., 2016) relatively few have 97 systematically investigated the compound-specific stable isotope composition of leaf 98 wax components in soils (Chikaraishi and Naraoka, 2006; Krull et al., 2006; Jia et al., 99 2008; Luo et al., 2011; Schwab et al., 2015; Zech et al., 2015). As waxes are initially 100 deposited in soils, soils serve as an intermediate reservoir before ultimate deposition in 101 lacustrine or marine archives. Soils therefore, better reflect the integrated source of plant 102 wax for such archives. It is known that certain plant functional types produce a higher 103 amount of leaf wax than others (Diefendorf et al., 2011; Bush and Mclnerney, 2013; Carr 104 et al., 2014), so the relative contributions of leaf waxes from different plant types may 105 differ significantly from their relative proportions in terms of vegetation cover. It is shown 106 that site averages of plants mitigate the effects of large interspecies variability in $\delta D_{\text {wax }}$ 107 and therefore better reflect source water $\delta D$ (Feakins and Sessions, 2010a).

The aim of this work is to evaluate the influence of different environmental factors

109 on the $\delta D_{\operatorname{wax}}$ composition of soils from southern Africa. Here, we consider compound-

110 specific $\delta D_{\text {wax }}$ of $n$-alkanes across soils collected along transects in South Africa. These

111 transects cover a wide range of climatic conditions and vegetation types. We compared

112 our data with predicted hydrogen isotope composition of precipitation, obtained from the

113 Online Isotopes in Precipitation Calculator (OIPC; Bowen and Revenaugh, 2003), and 
114 groundwater (West et al., 2014) as well as compound specific $\delta^{13} \mathrm{C}$ composition

115 (Herrmann et al., 2016) to address the following questions:

116 (i) Does $\delta D_{\text {wax }}$ in southern African soils reflect the stable hydrogen composition of $117 \quad$ precipitation $\left(\delta D_{p}\right) ?$

118 (ii) What additional factors influence $\delta D_{\text {wax }}$ ?

119 (iii) What are the implications for (palaeo-)environmental reconstructions utilising $120 \delta D_{\text {wax }}$ in southern Africa?

121 2. Study area

122 2.1. Climate

123 Southern Africa experiences pronounced precipitation seasonality, and seasonality

124 variability (Fig. 1a, c), driven by seasonal changes in large-scale atmospheric and 125 oceanic circulation systems (Tyson and Preston-Whyte, 2000). The eastern and central 126 parts of South Africa receive most ( $>66 \%$ ) of their mean annual precipitation (MAP) 127 between October and March, sourced from the Indian Ocean and brought by tropical 128 easterlies. This is commonly referred to as the summer rainfall zone (SRZ, sensu Chase 129 and Meadows, 2007). In contrast, the southwestern margin of South Africa is influenced 130 by frontal systems associated with the westerly storm tracks (Tyson, 1986) and receives $131>66 \%$ of its MAP during the austral winter. This region is therefore called the winter 132 rainfall zone (WRZ; Chase and Meadows, 2007). Between the WRZ and SRZ, a 133 dynamic transition zone is affected by both tropical and temperate systems and receives 134 a more equitable distribution of precipitation during the year, but with significant inter135 annual variability. This zone is often referred to as the year-round rainfall zone (YRZ).

136 Combined with strong variation in precipitation seasonality, South Africa also shows a 
137 pronounced precipitation gradient (Fig. 1a) from the arid western margin with very low

138 MAP (ca. $50 \mathrm{~mm} / \mathrm{yr}$ ) increasing to the Drakensberg mountains (ca. $1200 \mathrm{~mm} / \mathrm{yr}$ ) in the

139 east, and peaking at ca. $1700 \mathrm{~mm} / \mathrm{yr}$ in the northeast of the country. A weaker gradient

140 of increasing rainfall to the southwestern tip (ca. $1100 \mathrm{~mm} / \mathrm{yr}$ ) is also observed (Hijmans

141 et al., 2005). Apart from the pronounced rainfall gradient, the mean annual temperature

142 (MAT) also varies significantly from 5 to $24{ }^{\circ} \mathrm{C}$. Highest temperatures occur in the

143 northwest and northeast, whereas the coldest temperatures are related to higher

144 elevation (> $3000 \mathrm{~m}$ above sea level), most notably in the Drakensberg mountains

145 (Hijmans et al., 2005). This interplay of precipitation and temperature leads to general

146 higher aridity in the north-western and central parts vs. southwestern and eastern South

147 Africa.

148 2.2. Vegetation

149 Climatic conditions strongly shape the vegetation distribution in South Africa (Fig. 1b).

150 The biomes comprise the Desert and Succulent Karoo Biomes in the west, the Fynbos

151 Biome of the Cape, the Afromontane Forest, Thicket and Coastal Forests of the 152 southern and Indian Ocean margins, and the Nama Karoo, Grassland and Savanna

153 Biomes of the interior (Cowling et al., 1997; Mucina and Rutherford, 2006). These

154 biomes are characterised by a variety of plant functional types (Mucina and Rutherford,

155 2006). Woody $\mathrm{C}_{3}$ plants and $\mathrm{C}_{3}$ grasses dominate the Fynbos Biome and in cool, high-

156 altitude grasslands of the Drakensberg Mountains (Fig. 1d). In contrast, $\mathrm{C}_{4}$ grasses

157 dominate the Grassland and Savanna Biomes of the interior (Werger and Ellis, 1981),

158 reflecting increased aridity and particularly high (summer) growing season temperatures

159 (Vogel, 1978; Scott and Vogel, 2000). Plants using crassulacean acid metabolism

160 (CAM), including many succulents, are dominant in arid regions with high rainfall 
seasonality, such as in the Succulent Karoo and western Nama Karoo, but also exist in

162 abundance in other biomes (Mooney et al., 1977; Werger and Ellis, 1981).

163 3. Material and methods

164 3.1. Sampling

165 Soil samples were collected in 2010, 2012 and 2013 (Fig. 1). Part of the sampling in the

166 Succulent Karoo and Fynbos biomes in 2010 was carried out via a series of $10 \times 10 \mathrm{~m}$

167 vegetation survey plots. For the other sites, three samples from a 10-20 m radius were

168 collected, but were not associated with detailed vegetation surveys. Soils from the

169 survey plots were collected from the upper 10 to $15 \mathrm{~cm}$ (A horizon with removed litter

170 layer) at four fixed locations within each plot (see Carr et al., 2013).

\section{$171 \quad 3.2 . \quad$ Preparation and lipid extraction}

172 The samples were freeze-dried at the University of Leicester and were ground using an

173 agate mortar and pestle after removal of root and stem pieces. They were extracted $3 x$

174 with an accelerated solvent extractor (ASE200) using 9:1 dichloromethane (DCM) and

$175 \mathrm{MeOH}$ at $100{ }^{\circ} \mathrm{C}, 1000$ psi for 5 min. Squalane was added as internal standard in known

176 amount before extraction. Blank samples (combusted sand) contained only trace

177 amounts of lipids. Each total lipid extract (TLE) was concentrated using rotary

178 evaporation. The TLE was separated into hexane-insoluble and hexane-soluble fractions

179 by pipette column chromatography consisting of $4 \mathrm{~cm}$ sodium sulphate $\left(\mathrm{Na}_{2} \mathrm{SO}_{4}\right)$. The

180 hexane-soluble fraction was saponified with $0.1 \mathrm{M} \mathrm{KOH}$ in $\mathrm{MeOH}$ at $85{ }^{\circ} \mathrm{C}$ for $2 \mathrm{~h}$.

181 Neutral compounds were then extracted with hexane. The hydrocarbons were obtained

182 from the neutral fraction via pipette column chromatography consisting of $4 \mathrm{~cm}$ of

183 deactivated silica gel $\left(60\right.$ mesh, $\left.1 \% \mathrm{H}_{2} \mathrm{O}\right)$ using ca. $4 \mathrm{ml}$ of hexane. The hydrocarbons 
184 were separated into unsaturated and saturated hydrocarbon compounds by pipette

185 column chromatography loaded with $\mathrm{AgNO}_{3}-\mathrm{Si}$-coated $(4 \mathrm{~cm})$ using ca. $4 \mathrm{ml}$ of hexane 186 as solvent.

187 Some soil samples had high contents of cyclic and branched hydrocarbons, 188 which complicate the identification and separation of individual $n$-alkanes for compound189 specific isotope analysis. In these cases urea adduction was carried out to separate $n$ 190 alkanes from cyclic and branched hydrocarbons. To this end, $4.5 \mathrm{ml}$ hexane/DCM (2:1) 191 and $1.5 \mathrm{ml}$ urea solution $(40 \mathrm{mg} / \mathrm{ml}$ in $\mathrm{MeOH})$ were added to the hydrocarbon fraction 192 and cooled to $4{ }^{\circ} \mathrm{C}$ for $15 \mathrm{~min}$ and then dried under $\mathrm{N}_{2}$. Hexane was then added and 193 removed after vortexing for $30 \mathrm{~s}$ with a pipette. The procedure was conducted 3 times.

194 MilliQ water was added to dissolve the urea crystals and $n$-alkanes were extracted using 195 hexane/DCM (4:1).

196 3.3. Instrumental analysis

197 Quantification of long chain $n$-alkanes was conducted using a ThermoFischer Scientific

198 Focus gas chromatograph equipped with a Rxi-5 ms 30 column $(30 \mathrm{~m}, 0.25 \mathrm{~mm}$, $1990.25 \mu \mathrm{m}$ ), split/splitless injectior operating at $260^{\circ} \mathrm{C}$ and a flame ionization detector (GC200 FID). Helium was used as carrier gas at $1.9 \mathrm{~mL} \mathrm{~min}^{-1}$. Samples were injected in hexane 201 and the $\mathrm{GC}$ temperature was programmed to increase from $60^{\circ} \mathrm{C}\left(2 \mathrm{~min}\right.$ hold) to $150^{\circ} \mathrm{C}$ 202 with $20^{\circ} \mathrm{C} / \mathrm{min}$, and then with $4^{\circ} \mathrm{C} / \mathrm{min}$ to $320^{\circ} \mathrm{C}$ (held for $11 \mathrm{~min}$ ). An external standard 203 was used for quantification containing $n-\mathrm{C}_{18}$ to $n-\mathrm{C}_{34}$ alkanes in known concentration. 204 Repeated analyses of the external standard resulted in a quantification precision of $5 \%$.

205 Compound-specific $\delta \mathrm{D}$ analysis of leaf wax $n$-alkanes were carried out using a 206 ThermoFischer Scientific Trace GC equipped with a HP-5 ms column (30 m, $0.25 \mathrm{~mm}, 1$ 
$207 \mu \mathrm{m})$ coupled via a pyrolysis reactor operated at $1420{ }^{\circ} \mathrm{C}$ to a ThermoFischer MAT 253

208 isotope ratio mass spectrometer. Helium was used as carrier gas at $1.2 \mathrm{~mL} \mathrm{~min}{ }^{-1}$. The 209 samples were injected into a PTV injector at $45^{\circ} \mathrm{C}$ and then transferred onto the GC 210 column. The GC temperature was programmed to increase from $120^{\circ} \mathrm{C}$ ( 3 min hold) to $211200^{\circ} \mathrm{C}$ with $30{ }^{\circ} \mathrm{C} / \mathrm{min}$, and then with $4^{\circ} \mathrm{C} / \mathrm{min}$ to $320^{\circ} \mathrm{C}$ (held for $24 \mathrm{~min}$ ). All 212 measurements were calibrated against $\mathrm{H}_{2}$ reference gas $(\delta \mathrm{D}=-337 \pm 3 \%$ ) which $\delta \mathrm{D}$ 213 value was determined by analyses of four IAEA water standards using a ThermoFisher

214 Scientific thermal conversion/elemental analyser. All $\delta \mathrm{D}$ values are given in permil (\%o) 215 relative to Vienna Standard Mean Ocean Water (VSMOW). The daily measured $\mathrm{H}_{3}^{+}$ 216 factor varied between 5.2 and $5.4 \mathrm{ppm} \mathrm{n} / \mathrm{A}$ during the analysis period with maximum 217 variation of $0.1 \mathrm{ppm} \mathrm{n} / \mathrm{A}$ from day to day. A laboratory standard, containing of $15 \mathrm{n}$ 218 alkanes and squalane with known isotopic composition (ranging from -261 to $-33 \%$ ), 219 was measured before each sample sequence and after every six sample measurements 220 and yielded a long term accuracy and precision of 0 and 2.3\%o $(n>5000)$, respectively.

221 The laboratory standard was measured routinely against offline-determined standards 222 (mixtures of $n$-alkanes "Arndt B2" from Arndt Schimmelmann, Department of Geological 223 Sciences, Indiana University) with isotopic offsets within analytical error. Data 224 processing was accomplished using Isodat software 3.0. For each samples at least a 225 duplicate measurement was obtained and the averaged precision was $1 \%$ for the 226 homologues $n-\mathrm{C}_{29}$ and $n-\mathrm{C}_{31}$. The precision of the internal standard (squalane) was $2 \%$ $227(n=50)$. Compound-specific $\delta^{13} \mathrm{C}$ values have been reported before (Herrmann et al., 228 2016).

229 3.4. Climate data 
230 Site-specific mean annual precipitation (MAP), mean annual temperature (MAT), the

231 seasonality of precipitation and temperature, as well as the monthly and quarterly 232 precipitation and temperature extremes, were obtained from WorldClim 1.4 (Hijmans et 233 al., 2005). The data are based on interpolation of average monthly climate data from 234 weather stations on a 30 arc-second $\left(\right.$ ca. $1 \mathrm{~km}^{2}$ ) resolution grid. The aridity index and 235 potential evapotranspiration (PET) data were obtained from the CGIAR-CSI GeoPortal 236 on a 30 arc-second (ca. $1 \mathrm{~km}^{2}$ ) resolution grid (Trabucco and Zomer, 2009).

237 3.5. $\delta D$ of precipitation and groundwater

238 Annual average and monthly data for $\delta \mathrm{D}$ of precipitation $\left(\delta \mathrm{D}_{\mathrm{p}}\right)$ were obtained from the 239 online isotopes in precipitation calculator (OIPC, www.waterisotopes.org, accessed April 240 2014) using a 10' resolution grid (Bowen and Revenaugh, 2003; Bowen et al., 2005). 241 The data are based on interpolation of the $\mathrm{D}$ isotope composition of precipitation 242 obtained from the Global Network for Isotopes in Precipitation (GNIP) database. The $24395 \%$ confidence interval of interpolated $\delta D_{p}$ ranges between 3 and $6 \%$ for the study area 244 in South Africa (Bowen and Revenaugh, 2003). Note that the coverage of $\delta D_{p}$ 245 monitoring weather stations is poor in southern Africa (two stations, one in Pretoria and 246 one in Cape Town), and therefore the accuracy of the interpolated isotope distribution 247 may be limited. A comparison of annual $\delta D_{p}$ and MAP along the soil transects revealed 248 a strong negative correlation, suggesting control via the amount effect in the SRZ ( $r$ $2490.84, p<0.001)$, whereas annual $\delta D_{p}$ and MAP showed a weak correlation in the $\mathrm{YRZ}(\mathrm{r}$ $250-0.67, p 0.143)$ and no correlation in the WRZ ( $r-0.33, p 0.130$; Fig. 2). Consistent with 251 this, a 12-yr record from Cape Town (WRZ) showed a weak amount effect and 252 temperature effect (Harris et al., 2010). In contrast $\delta D_{p}$ correlates negatively with altitude 
253 in the SRZ and the WRZ (Supplementary material Fig. 1). For further analysis, additional

$254 \delta$ D values for groundwater were obtained from West et al. (2014). They are based on

255 spatial analysis of measured $\delta \mathrm{D}$ values of groundwater $\left(\delta \mathrm{D}_{\mathrm{g}}\right)$ from 369 monitoring 256 locations across South Africa sampled between April 2006 and September 2007 (West 257 et al., 2014). The standard deviation of $\delta D_{g}$ ranges between 6.6 and $7.3 \%$.

258 4. Results \& Discussion

259 4.1. Source of soil n-alkanes

260 In an earlier study of the same soil samples (Herrmann et al., 2016) we found a 261 predominance of long-chain $n$-alkanes and CPI values of higher than 4 in most soil 262 samples indicating a terrestrial higher plants origin and a relatively non-degraded state. 263 We also showed that, on average, $n$-alkane distributions and compound-specific $\delta^{13} \mathrm{C}$ 264 compositions differ across the individual biomes reflecting their different vegetation 265 types, despite of a large variability of individual samples (Herrmann et al., 2016). Even 266 though we cannot completely rule out an additional input of wind transported leaf waxes, 267 a strong site-by-site correlation between plant and soil wax distributions has previously 268 been shown for the Succulent Karoo and Fynbos soils (Carr et al., 2013, 2014; 269 Herrmann et al., 2016). Further, studies have been shown, that input of aeolian 270 transported material is negligible south of $25^{\circ} \mathrm{S}$ (Prospero et al., 2002; Dupont and 271 Wyputta, 2003; Eckardt and Kuring, 2005; Vickery et al., 2013). Therefore, we expect 272 that the bulk of soil $n$-alkanes shows a predominant local signal (Herrmann et al., 2016).

273 An additional unknown factor in our studied soils is the residence time of plant wax 274 biomarkers in the soils, which might be very long, i.e. up to millennia, depending on 275 environmental conditions (Conte and Weber, 2002; Drenzek et al., 2007; Kusch et al., 
276 2010; Galy et al., 2011). Therefore, $\delta D_{\text {wax }}$ potentially incorporates much older $\delta D_{p}$

277 signals. As we have no compound-specific ${ }^{14} \mathrm{C}$ dating for our samples, we cannot rule

278 out large discrepancies of leaf wax ages in the soils. However, radiocarbon dating on

279 bulk total organic carbon of Grassland (location GTC9) and Savanna (location GTC24)

280 soils results in modern ages (post-1950; Herrmann et al., 2016).

281 For further discussion we focused on the $n-C_{29}$ and $n-C_{31}$ alkanes as they are 282 typically used for (palaeo-)climatic studies (e.g. Sachse et al., 2006; Aichner et al., 2010) 283 with the latter being the most abundant homologue in our samples (Herrmann et al., 284 2016). The concentrations for $n-C_{29}$ and $n-C_{31}$ in all samples are presented in the 285 Supplementary Table and range between 0.05 and $5.3 \mu \mathrm{g} / \mathrm{g}$ dry weight ( $\mathrm{dw}$ ) and 0.2 to $28629 \mu \mathrm{g} / \mathrm{g} \mathrm{dw}$ for $n-\mathrm{C}_{29}$ and $n-\mathrm{C}_{31}$, respectively. Intra-site variation is between $4.4 \mu \mathrm{g} / \mathrm{g} \mathrm{dw}$ $287 \quad\left(n-\mathrm{C}_{29}\right)$ and $26 \mu \mathrm{g} / \mathrm{g} \mathrm{dw}\left(n-\mathrm{C}_{31}\right)$.

288 4.2. Relationship between $\delta D_{w a x}, \delta D_{p}$ and $\delta D_{g}$

$289 \delta D_{\text {wax }}$ vary from -75 to $-151 \%$ for $n-\mathrm{C}_{29}$ and -105 to $-161 \%$ for $n-\mathrm{C}_{31}$ (Supplementary 290 Table). The intra-site variation spanned a range of 1 to $41 \%$ for $n-C_{29}$ and 0 to $30 \%$ for $291 n-C_{31}$. We calculated the amount-weighted mean $\delta D_{\text {wax }}$ of both homologues $\left(n-C_{29}\right.$ and $\left.292 n-C_{31}\right)$ for each soil sample and then the amount-weighted mean of soils from each plot 293 to obtain a vegetation-integrated $\delta D_{\text {wax }}$ signal for each location. For the SRZ, the most 294 negative $\delta D_{\text {wax }}$ values are found for the grassland biome, with a gradual increase further 295 west in the Nama Karoo biome (Table 1).

296 Several studies show a correlation between $\delta D_{\text {wax }}$ and $\delta D_{p}$ for different 297 ecosystems (Sachse et al., 2006; Smith and Freeman, 2006; Polissar and Freeman, 298 2010; Garcin et al., 2012; Berke et al., 2015; Schwab et al., 2015; Feakins et al., 2016). 
299 However, there is no correlation between $\delta D_{\text {wax }}$ and annual $\delta D_{p}(r-0.12, p 0.41)$, if all 300 locations across this study area are included (Table 2). Considering the distinct rainfall 301 zones separately, however, we observe a different picture. In the $S R Z \delta D_{\text {wax }}$ is 302 correlated significantly with annual $\delta D_{p}(r 0.65, p<0.01)($, Table 2), suggesting that $303 \delta D_{\text {wax }}$ reflects the $\delta \mathrm{D}$ signal of annual precipitation. However, the range (Table 1) of $304 \delta D_{\text {wax }}(49 \%)$ is substantially wider than for $\delta D_{p}(17 \%)$ in the SRZ. In the drier regions of

305 South Africa soil water is likely to be more affected by evaporation, leading to a $D$ 306 enrichment of soil water and therefore D enriched source water for plants. Additionally, 307 earlier studies found $D$ enriched leaf water due to greater leaf transpiration in drier 308 regions (Smith and Freeman, 2006; Aichner et al., 2010; Sachse et al., 2012; Kahmen et 309 al., 2013a, 2013b). As a consequence this combined evapotranspiration leads to higher $310 \delta D_{\text {wax }}$ composition in drier areas (Smith and Freeman, 2006; Feakins and Sessions, 311 2010a; McInerney et al., 2011; Douglas et al., 2012; Kahmen et al., 2013a). Therefore 312 the greater range in $\delta D_{\text {wax }}$ than in $\delta D_{p}$ is not unexpected.

$313 \delta D_{\text {wax }}$ values for the $W R Z$ show a gradual increase from the southern Fynbos to 314 the more northern Succulent Karoo biome and a narrower range (Table 1) than for the 315 SRZ. Contrary to the SRZ, the area of the WRZ is much smaller, which leads to reduced 316 distance from the moisture source in the Atlantic Ocean and therefore to a slightly 317 narrower range of $\delta D_{p}(15 \%)$. The $W R Z$ is, however, affected not only by rain bearing 318 systems from the Atlantic Ocean but also by moisture derived from the southeast (Tyson 319 and Preston-Whyte, 2000), which becomes more important for the south-eastern part. 320 This overlap can complicate the assignment of moisture sources. It has been shown that 321 rain generation in frontal systems is complex, and a clear relationship between isotopic 
322 composition and precipitation amount is lacking (Harris et al., 2010). The topography of

323 the WRZ serves to complicate such relationships further with the Cape Fold Mountains a 324 source of much greater topographic/microclimatic variability than the interior. The 325 resulting orographic effects will lead to specific microclimates in mountainous areas of 326 the WRZ, including higher precipitation rates on the windward sides of slopes and lower 327 rates on the leeward sides (Houze, 2012), as well as small scale differences in $\delta D_{p}$ 328 composition due to local convection and rainout (Harris et al., 2010), as described for 329 other mountain areas (Holdsworth et al., 1991; Araguás-Araguás et al., 2000; Bowen 330 and Revenaugh, 2003). Such small-scale variations are likely not reflected in the 331 modelled $\delta \mathrm{D}_{\mathrm{p}}$. These complex and small-scale processes may explain the weak 332 correlation between $\delta D_{\text {wax }}$ and annual $\delta D_{p}$ for the $W R Z(r-0.48, p 0.02)$ (, Table 2). For 333 the driest season (summer months: DJF) we found a weak correlation between $\delta D_{\text {wax }}$ 334 and $\delta D_{p}(r-0.48, p 0.03)$, corroborating findings that summer rains might be an important 335 water source, at least for some parts of the WRZ (Chase et al., 2015b). This correlation 336 is stronger for Succulent Karoo soils $(r-0.58, p 0.03)$, whereas in the Fynbos biome no 337 correlation ( $r-0.42, p 0.26)$ is observed (Table 2). Plants may use water vapour, cloud 338 moisture and fog as additional moisture sources (e.g. Rundel et al., 1991; Soderberg, 339 2010; West et al., 2012; Matimati et al., 2013). The moisture uptake from water vapour 340 and fog can be nearly equivalent to the amount of precipitation in the Succulent Karoo 341 (Matimati et al., 2013), while cloud moisture adds to moisture uptake in the Fynbos 342 (West et al., 2012) possibly imprint the $\delta D_{\text {wax }}$ signal.

343 In addition, differences of plant functional types, species and photosynthetic 344 pathways between the Succulent Karoo and Fynbos (Mucina and Rutherford, 2006) 
345 could have an impact on the $\delta \mathrm{D}$ composition of leaf wax components in WRZ soils as 346 different plant types and photosynthetic pathways show different $D$ enrichment factors 347 (e.g. Smith and Freeman, 2006; Hou et al., 2007b; Liu and Yang, 2008; Mclnerney et al., 348 2011; Gao et al., 2014; Gamarra et al., 2016). In the YRZ, we observe a correlation 349 between $\delta D_{\text {wax }}$ and $\delta D_{p}(r 0.82, p 0.04)$, with higher $\delta D_{\text {wax }}$ in the northern (mean $-109 \pm$ $3505 \%$ ) than in the southern (mean $-129 \pm 3 \%$ ) areas (see Supplementary Table). The 351 higher $\delta D_{\text {wax }}$ in the northern areas appears to be an extension of the westward 352 enrichment trend in the SRZ, affirmed by higher precipitation amounts in the northern 353 YRZ from November to April (Hijmans et al., 2005). In contrast, for the southern 354 locations of the $Y R Z$ the period of the highest precipitation lasts from March to June/July 355 (Hijmans et al., 2005). Thus, the southern YRZ locations are more affected by winter 356 precipitation and the northern locations by summer precipitation. For this reason we 357 attribute the northern samples from the $Y R Z$ to the SRZ and the southern samples to the 358 WRZ in the discussion below. Including these locations in SRZ and WRZ, respectively, 359 improves the correlations for $\delta D_{\text {wax }}$ and annual $\delta D_{p}$ in the $S R Z(r 0.66, p<0.001)$ as well 360 as $\delta D_{\text {wax }}$ and $\delta D_{p}$ during the driest quarter in the WRZ $(r-0.52, p<0.01$; Fig. 3).

361 We also compare our $\delta \mathrm{D}_{\text {wax }}$ data with $\delta \mathrm{D}_{g}$ of groundwater. The latter has been 362 suggested to reflect the $\delta \mathrm{D}$ of precipitation (Rozanski, 1985; Kortelainen and Karhu, 363 2004; West et al., 2014), at least during the main precipitation season (Wassenaar et al., 364 2009). For the $S R Z$ the relationship between $\delta D_{\text {wax }}$ and $\delta D_{g}$ is slightly stronger $(r-0.73, p$ $365<0.001)$ than that for $\delta D_{\text {wax }}$ and $\delta D_{p}$, but surprisingly $\delta D_{g}$ is inversely correlated with $\delta D_{p}$

366 (Fig. 4). The $\delta D_{g}$ values are more depleted in the semi-arid than in the wetter regions, 367 contrary to the trend in the OIPC data. Many studies have shown that shallow 
368 groundwater reflects $\delta D_{p}$ (e.g. Kortelainen and Karhu, 2004; Rozanski, 1985;

369 Wassenaar et al., 2009), and here this is apparent for the WRZ (Fig. 4; Diamond, 2014).

370 In contrast, in the arid regions of southern Africa, groundwater may be deeper (de Vries

371 et al., 2000; Musekiwa and Majola, 2013), and out of the reach of roots. It may also

372 incorporate older water, that could carries an isotopic signature different from modern

373 precipitation (de Vries et al., 2000). The implication is therefore that plants in arid parts

374 of the SRZ use water immediately from precipitation events and that the OIPC provides

375 the most useful $\delta \mathrm{D}$ data of the plants' water source, in the present absence of other

376 data, for interpretations of $\delta D_{\text {wax }}$.

377 4.3. Apparent fractionation factor ( $\left.\varepsilon_{a p p}\right)$ for plant wax derived $n$-alkanes in soils

378 To evaluate the influence of vegetation and other environmental factors, e.g.

379 precipitation, aridity and temperature, on the $\delta D_{\text {wax }}$ composition, we calculate the 380 apparent fractionation $\left(\varepsilon_{\mathrm{app}}\right)$ between $\delta \mathrm{D}_{\text {wax }}$ and $\delta \mathrm{D}$ of precipitation during the growing 381 season $\left(\delta D_{p g s}\right)$ as:

382

$$
\varepsilon_{a p p}=\left(\frac{\delta \mathrm{D}_{\text {wax }}+1000}{\delta \mathrm{D}_{\text {pgs }}+1000}-1\right) * 1000
$$

383 The $\delta D_{p g s}$ was calculated as amount-weighted mean of the monthly $\delta D_{p}$ values from 384 OIPC. As the seasonality of rainfall is responsible for the water availability and $\delta D_{\text {wax }}$ 385 well reflects $\delta D_{p}$ of the growing season in semiarid regions (Niedermeyer et al., 2016),

386 we assume a limited recharge of soil water and plant growth during the non-growing 387 season and, therefore, a limited bias of $\delta \mathrm{D}_{\text {wax }}$ towards the non-growing season. To 388 determine the length of growing season for each location we used the definition of the 
389 Food and Agriculture Organization of the United Nations (FAO), defined as the period 390 where the precipitation exceeds half of the potential evapotranspiration:

$$
\text { Growing season: } \frac{\text { precip }_{x}}{P E T_{x}} \geq 0.5
$$

392 where $\mathrm{x}$ represents the individual month. For some locations, especially in the Nama 393 Karoo, this definition results in a growing season of zero months. Therefore, we used the 394 month with the highest precipitation/PET ratio as growing season in such cases.

395 Like $\delta D_{\text {wax }}$, Eapp shows a wide variability, ranging from -83 to $-141 \%$ o (Fig. 5) with 396 individual uncertainties of 0 to $11 \%$ (Supplementary Table). The smallest Eapp is 397 observed for the Nama Karoo biome and the largest are measured in the Fynbos and 398 Grassland biomes (Fig. 5). The $\varepsilon$ app becomes smaller with distance from the Atlantic and 399 Indian Ocean moisture sources (Fig. 5). In general, there is less apparent fractionation 400 for plants contributing to the soils located in more arid regions of the SRZ compared to 401 more humid parts of the SRZ (Fig. 6), The overall SRZ correlation between $\varepsilon_{\text {app }}$ and 402 MAP is strong $\left(r-0.75, p<0.001\right.$; Fig. 7) as is the correlation between $\varepsilon_{\text {app }}$ and 403 precipitation during the growing season $(r-0.75, p<0.001$; Table 3, Supplementary 404 material Fig. 2). On average, less apparent fractionation occurs in the summer rainfall 405 biomes compared with the winter rainfall dominated biomes (two-tailed student's test: $p$ $406<0.001$; Fig. 6). Our general observation of lower apparent fractionation for drier 407 environments of the SRZ is similar to other studies in arid regions (Smith and Freeman, 408 2006; Feakins and Sessions, 2010a; Kahmen et al., 2013a; Berke et al., 2015). By 409 contrast, no correlation is observed between $\varepsilon_{\text {app }}$ and MAP (Fig. 7) or $\varepsilon_{\text {app }}$ and growing 410 season precipitation for the WRZ (Supplementary material Fig. 2), even if Fynbos and 
411 Succulent Karoo biomes are considered separately (Table 3, Supplementary material

412 Fig. 3). This suggests imprints other than solely precipitation amount on $\varepsilon_{\text {app. }}$.

413 4.4. Factors influencing deuterium fractionation of leaf wax components in southern $414 \quad$ Africa

415 We compare $\varepsilon_{\text {app }}$ with other environmental data (i.e. aridity, altitude, temperature, PET, $\left.416 \delta^{13} \mathrm{C}_{\text {wax }}\right)$ to evaluate their imprints on $\delta \mathrm{D}_{\text {wax }}$ composition and apparent fractionation.

417 Table 3 gives an overview of the relationships between $\varepsilon_{a p p}$ and environmental 418 parameters divided into the different rainfall zones and biomes.

419 4.4.1. $S R Z$

420 For the SRZ, $\varepsilon_{\text {app }}$ correlates significantly with the amount of precipitation during the 421 growing season $(r-0.75, p<0.001)$, MAP $(r-0.75, p<0.001)$, aridity index $(r-0.74, p<$ $4220.001)$, maximum temperature during the warmest month $(r 0.72, p<0.001)$ as well as 423 other environmental factors listed in Table 3. There is lower apparent fractionation in 424 more arid regions of the SRZ (Fig. 7). This may be caused by several factors. As noted 425 above, D enrichment of soil water due to evaporation affects the isotope composition of 426 leaf waxes and therefore the apparent fractionation between leaf wax and precipitation. 427 Further, the significant correlation with growing season precipitation and MAP suggests 428 that SRZ plants use water immediately after a precipitation event, with a rapid uptake of 429 surface soil water by roots, as well as water from deeper soil layers that incorporate the 430 isotope signature of MAP (Ehleringer and Dawson, 1992; Schulze et al., 1996). Different 431 rooting strategies may influence $\delta D_{\text {wax }}$ composition (Dawson, 1993; Krull et al., 2006; 432 Feakins and Sessions, 2010a; Garcin et al., 2012) leading to lower apparent 433 fractionation in plants with shallower roots than those with deeper roots (Smith and 
434 Freeman, 2006; Berke et al., 2015). However, some studies infer D enrichment of leaf

435 water during leaf transpiration as (the most) important factor that influences apparent 436 fractionation (Smith and Freeman, 2006; Feakins and Sessions, 2010a; Zhou et al., 437 2011; Kahmen et al., 2013a). In the SRZ of South Africa, D enrichment of leaf water has 438 been previously modelled as ranging between $40 \%$ in the eastern regions and $70 \%$ in 439 the drier northwestern parts for the spring season (Kahmen et al., 2013a). The observed $440 \varepsilon_{\text {app }}$ range in our soil samples (ca. $50 \%$ ) is thus greater than the range for modelled leaf

441 water enrichment (ca. 30\%; Kahmen et al., 2013a). Nevertheless, both values, i.e. $\varepsilon_{\text {app }}$

442 of our soil samples and modelled leaf water enrichment, show higher values in the drier 443 western region of the $S R Z$, indicating that evaporative leaf water enrichment can 444 account for at least part of the detected change in apparent fractionation. Kahmen et al.

445 (2013a) concluded that in arid and temperate environments $\delta D_{\text {wax }}$ records $\delta D$ 446 composition of precipitation and evapotranspiration, whereas in (wet) tropical 447 environments $\delta D_{\text {wax }}$ records solely $\delta \mathrm{D}$ of precipitation. Our data for the SRZ support this 448 conclusion. The correlation between $\varepsilon_{\text {app }}$ and the amount of precipitation during the 449 growing season as well as the aridity index (a lower index indicating higher aridity, Fig. 450 7) and annual PET also indicate (Supplementary material Fig. 4) that aridity and 451 therefore evapotranspiration are important in influencing $\delta D_{\text {wax }}$ composition in the $S R Z$ 452 of southern Africa.

453 In contrast, we find no correlation between $\varepsilon_{\text {app }}$ and $\delta^{13} \mathrm{C}_{\text {wax }}$ (Table 3) suggesting 454 that the photosynthetic pathway is a negligible factor in influencing $\varepsilon_{\text {app. }}$. This 455 corroborates previous data, which show that photosynthetic pathway is not a decisive 456 factor controlling hydrogen isotope fractionation in plants (Krull et al., 2006). In contrast, 
457 other studies have shown greater $\mathrm{D}$ enrichment in $\mathrm{C}_{4}$ grasses (dicots) than in $\mathrm{C}_{3}$

458 grasses (dicots) (Smith and Freeman, 2006; Liu and Yang, 2008; Mclnerney et al., 2011;

459 Kahmen et al., 2013b). Additionally, earlier studies have shown a relationship between

$460 \delta^{13} \mathrm{C}$ and water use efficiency (WUE) of $\mathrm{C}_{3}$ plants (e.g. Farquhar et al., 1989; Ehleringer

461 and Dawson, 1992; Rundel et al., 1999). As such, Hou et al. (2007a) inferred that a

462 significant correlation between $\delta^{13} \mathrm{C}_{\text {wax }}$ and $\delta \mathrm{D}_{\operatorname{wax}}$ in tree leaves is related to changing

463 WUE. However, the data from Hou et al. (2007a) are derived solely from tree species

464 within a relatively small area, whereas the vegetation community of plants in southern

465 Africa is a mixture of $\mathrm{C}_{3}, \mathrm{C}_{4}$ and CAM plants. Whereas $\delta^{13} \mathrm{C}_{\text {wax }}$ and $\delta \mathrm{D}_{\text {wax }}$ were found to

466 correlate negatively for $\mathrm{C}_{3}$ plants (Bi et al., 2005; Hou et al., 2007a), $\mathrm{C}_{4}$ and CAM plants

467 showed positive correlations between $\delta^{13} \mathrm{C}_{\text {wax }}$ and $\delta \mathrm{D}_{\text {wax }}$ (Bi et al., 2005; Feakins and

468 Sessions, 2010b) potentially leading to an integrated signal in soils for which there is no 469 correlation between $\delta^{13} \mathrm{C}_{\mathrm{wax}}$ and $\delta \mathrm{D}_{\operatorname{wax}}$ (Supplementary material Fig. 5).

$470 \quad$ 4.4.2. $\quad W R Z$

471 In contrast to the SRZ, climatic/environmental parameters are mostly inversely 472 correlated with $\varepsilon_{\text {app }}$ (Table 3). Significant correlations are observed between $\varepsilon_{\text {app }}$ and the 473 annual range of temperature $(r 0.69, p<0.001)$ and between $\varepsilon_{\text {app }}$ and the minimum

474 temperature of the coldest quarter $(r-0.66, p<0.001)$ suggesting that temperature 475 conditions affect hydrogen isotope fractionation in this area. Temperature is known to be 476 an important driver for isotopic enrichment in leaf water (Barbour et al., 2000; Zhou et 477 al., 2011; Sachse et al., 2012). As the D composition of soil and plant water remains 478 unknown, we can only assume that the correlation of $\varepsilon_{\text {app }}$ with temperature is a result of 479 evapotranspiration (e.g. Mclnerney et al., 2011; Kahmen et al., 2013a, b) or fractionation 
480 during water uptake by plants (e.g. Smith and Freeman, 2006; Feakins and Sessions, 481 2010a). In the Succulent Karoo biome $\varepsilon_{\text {app }}$ correlates more strongly with temperature 482 (e.g. MAT: $r-0.69, p<0.01$ ) than in the Fynbos biome (MAT: $r-0.35, p 0.351$ ), whereas 483 for the latter $\varepsilon_{\text {app }}$ seems also affected by the PET during the growing season $(r 0.87, p<$ $484 \quad 0.01$; Fig. 8, Table 3).

485 Additionally, we observe that the seasonal availability of water might affect $\varepsilon_{\text {app }}(r$ $4860.67, p<0.001)$ in the WRZ. During the drier summer months, an increase in 487 precipitation could reduce drought stress for plants more effectively than a precipitation 488 increase during the wetter winter months (Chase et al., 2015a, b). Reduced drought 489 stress and a greater overall water availability would lead to greater apparent 490 fractionation (Feakins and Sessions, 2010a). Here, however, decreasing precipitation 491 seasonality or increasing precipitation during the dry summer months, which may reduce 492 drought stress, correlate with lower apparent fractionation. This is an unexpected 493 finding. Further, the correlation between precipitation of the dry summer months and $\varepsilon_{\text {app }}$ 494 only exists for the Succulent Karoo $(r \quad 0.77, p<0.001)$ and not for the Fynbos biome $(r$ 495 0.36, $p$ 0.344), indicating the possible importance of summer precipitation in the 496 Succulent Karoo.

497 Differences in the vegetation communities between the Succulent Karoo and 498 Fynbos could be another factor for the observed inverse correlations. In the Karoo, 499 succulents and shrubs develop shallow roots utilizing surface soil water enriched by 500 evaporation (Esler and Rundel, 1999; Shiponeni et al., 2011) including summer 501 precipitation. Most WRZ succulents are CAM plants (Mooney et al., 1977; Boom et al., 502 2014), which were found to have substantially smaller net apparent fractionation than $\mathrm{C}_{3}$ 
503 or $\mathrm{C}_{4}$ plants (Feakins and Sessions, 2010b). Succulents produce much higher amounts

504 of wax than, for instance, grasses (Carr et al., 2014; Garcin et al., 2014), which is also 505 reflected in our soil samples (Herrmann et al., 2016). Therefore, $\delta D_{\text {wax }}$ might represent 506 mainly the shallow rooting plants in the Succulent Karoo. In contrast, Fynbos consists of 507 shallow rooted graminoids and shrubs as well as deep rooted shrubs (Hawkins et al., 508 2009; West et al., 2012).

509 Despite the dependence of $\delta D_{p}$ and $\varepsilon_{\mathrm{app}}$ on the altitude large topographic changes 510 in the WRZ could cause microclimatic differences between the Succulent Karoo and

511 Fynbos at small spatial scales (Mucina and Rutherford, 2006). This and water uptake by 512 other moisture sources than precipitation as well as different functional plant types 513 between the Succulent Karoo and Fynbos biome may hamper the detection of an

514 obvious relationship between apparent fractionation and environmental parameters.

515 Further investigations are needed to evaluate how $\delta D_{p}$ relates to $\delta D_{\text {wax }}$ for the WRZ.

516 Investigations of $\delta \mathrm{D}_{\operatorname{wax}}$ from plants and soils along distinct climatic and environmental

517 gradients within the WRZ might solve these questions.

518 5. Conclusions and palaeoenvironmental implications

519 We report plant wax $\delta \mathrm{D}$ compositions in soils from various transects in southern Africa 520 comprising a variety of precipitation regimes and vegetation communities. Overall, our 521 study confirms earlier findings using $\delta D_{\text {wax }}$ as a palaeohydrological proxy, and 522 demonstrates that the approach is suitable for climatic reconstruction in southern 523 Africa's SRZ. In semi-arid regions of the SRZ, where the growing season and therefore 524 plant wax production occurs during the warm summer season, the relationship between 
$525 \delta D_{\text {wax }}$ and (annual) $\delta D_{p}$ as well as MAP suggest that $\delta D_{\text {wax }}$ can be used to reconstruct

526 past precipitation amounts. Evapotranspiration, especially in the more arid parts of the

527 SRZ, lead to isotope enrichment in soil and leaf water and thus less apparent hydrogen

528 isotope fractionation. This effect compromises quantitative precipitation reconstruction.

529 Vegetation changes appear to exert a minor influence on apparent fractionation and $530 \delta \mathrm{D}_{\text {wax }}$ composition. Variations in $\delta \mathrm{D}_{\text {wax }}$ in sedimentary archives of the $\mathrm{SRZ}$ are thus well-

531 suited for qualitative palaeohydrological reconstruction.

532 In contrast, in the southern African winter rainfall zone, $\delta D_{\text {wax }}$ values do not reflect

533 annual or growing season $\delta \mathrm{D}_{\mathrm{p}}$. In this area of high topographic variability, distinct

534 microclimatic conditions exist on small spatial scales, likely causing $\delta D_{p}$ variation 535 unresolved by the OIPC, but also leading to distinct vegetation communities and 536 vegetation variability as well as potentially differences of additional moisture sources 537 between the biomes in the WRZ. While temperature may be a potential driver for 538 variations in the dry Succulent Karoo biome, potential evapotranspiration seems more 539 important in the Fynbos biome. Further, we detect a potential influence of summer

540 precipitation on the $\delta D_{\text {wax }}$ in the WRZ. Interpretation of past hydrological changes in the

541 WRZ based on $\delta D_{\text {wax }}$ require more care, supported perhaps by a multi proxy approach

542 including pollen, other stable isotopes and/or inorganic geochemical data, as well as a

543 more comprehensive data set for modern plants and soils across the climatic 544 environment of this region. For the WRZ, more research is needed to unravel the factors 545 influencing hydrogen isotope fractionation and $\delta D_{\text {wax }}$.

\section{Acknowledgements}


547 This study was funded by the German Bundesministerium für Bildung und Forschung 548 (BMBF) within the project "Regional Archives for Integrated Investigation" (RAiN, 549 03G0840A). N.H. was supported by GLOMAR - Bremen International Graduate School 550 for Marine Sciences. The work was also supported by the UK Leverhulme Trust (Grant 551 F/00 212/AF) and the European Research Council (ERC) Starting Grant "HYRAX" 552 (Grant Agreement No. 258657). R. Kreutz and O. Helten are thanked for analytical 553 assistance and T. Eickhorst for help with soil import. We thank the editors for their time 554 and valuable remarks and the two anonymous reviewers for their constructive 555 comments. 
Final version available at

http://www.sciencedirect.com/science/article/pii/S0146638016302273

556

557

558

559

560

561

562

563

564

565

566

567

568

569

570

571

572

573

574

575

576

577

578

579

580

581

582

583

584

585

586

587

588

589

590

591

592

593

594

595

596

597

\section{References}

Aichner, B., Herzschuh, U., Wilkes, H., Vieth, A., Böhner, J., 2010. $\delta$ D values of $n$ alkanes in Tibetan lake sediments and aquatic macrophytes - A surface sediment study and application to a 16ka record from Lake Koucha. Organic Geochemistry 41, 779-790. doi:10.1016/j.orggeochem.2010.05.010

Araguás-Araguás, L., Froehlich, K., Rozanski, K., 2000. Deuterium and ${ }^{18} \mathrm{O}$ isotope composition of precipitation and atmospheric moisture. Hydrological Processes 14, 1341-1355. doi:10.1002/1099-1085(20000615)14:8<1341::AID-HYP983>3.0.CO;2Z

Barbour, M.M., Fischer, R.A., Sayre, K.D., Farquhar, G.D., 2000. Oxygen isotope ratio of leaf and grain material correlates with stomatal conductance and grain yield in irrigated wheat. Functional Plant Biology 27, 625-637.

Berke, M.A., Tipple, B.J., Hambach, B., Ehleringer, J.R., 2015. Life form-specific gradients in compound-specific hydrogen isotope ratios of modern leaf waxes along a North American Monsoonal transect. Oecologia 179, 981-97. doi:10.1007/s00442-015-3432-1

Bi, X., Sheng, G., Liu, X., Li, C., Fu, J., 2005. Molecular and carbon and hydrogen isotopic composition of $n$-alkanes in plant leaf waxes. Organic Geochemistry 36, 1405-1417. doi:10.1016/j.orggeochem.2005.06.001

Boom, A., Carr, A.S., Chase, B.M., Grimes, H.L., Meadows, M.E., 2014. Leaf wax nalkanes and $\delta^{13} \mathrm{C}$ values of CAM plants from arid southwest Africa. Organic Geochemistry 67, 99-102. doi:10.1016/j.orggeochem.2013.12.005

Bowen, G.J., Revenaugh, J., 2003. Interpolating the isotopic composition of modern meteoric precipitation. Water Resources Research 39, 1299.

Bowen, G.J., Wassenaar, L.I., Hobson, K.A., 2005. Global application of stable hydrogen and oxygen isotopes to wildlife forensics. Oecologia 143, 337-48. doi:10.1007/s00442-004-1813-y

Bush, R.T., Mclnerney, F.A., 2013. Leaf wax $n$-alkane distributions in and across modern plants: Implications for paleoecology and chemotaxonomy. Geochimica et Cosmochimica Acta 117, 161-179. doi:10.1016/j.gca.2013.04.016

Carr, A.S., Boom, A., Chase, B.M., Meadows, M.E., Roberts, Z.E., Britton, M.N., Cumming, A.M.J., 2013. Biome-scale characterisation and differentiation of semiarid and arid zone soil organic matter compositions using pyrolysis-GC/MS analysis. Geoderma 200-201, 189-201. doi:10.1016/j.geoderma.2013.02.012

Carr, A.S., Boom, A., Grimes, H.L., Chase, B.M., Meadows, M.E., Harris, A., 2014. Leaf wax $n$-alkane distributions in arid zone South African flora: Environmental controls, chemotaxonomy and palaeoecological implications. Organic Geochemistry 67, 7284. doi:10.1016/j.orggeochem.2013.12.004

Chase, B.M., Boom, A., Carr, A.S., Carré, M., Chevalier, M., Meadows, M.E., Pedro, J.B., Stager, J.C., Reimer, P.J., 2015a. Evolving southwest African response to abrupt deglacial North Atlantic climate change events. Quaternary Science Reviews 121, 132-136. doi:10.1016/j.quascirev.2015.05.023 
598

599

600

601

602

603

604

605

606

607

608

609

610

611

612

613

614

615

616

617

618

619

620

621

622

623

624

625

626

627

628

629

630

631

632

633

634

635

636

637

638

639

Chase, B.M., Lim, S., Chevalier, M., Boom, A., Carr, A.S., Meadows, M.E., Reimer, P.J., 2015b. Influence of tropical easterlies in southern Africa's winter rainfall zone during the Holocene. Quaternary Science Reviews 107, 138-148. doi:10.1016/j.quascirev.2014.10.011

Chase, B.M., Meadows, M.E., 2007. Late Quaternary dynamics of southern Africa's winter rainfall zone. Earth-Science Reviews 84, 103-138. doi:10.1016/j.earscirev.2007.06.002

Chikaraishi, Y., Naraoka, H., 2006. Carbon and hydrogen isotope variation of plant biomarkers in a plant-soil system. Chemical Geology 231, 190-202. doi:10.1016/j.chemgeo.2006.01.026

Collins, J.A., Schefuß, E., Mulitza, S., Prange, M., Werner, M., Tharammal, T., Paul, A., Wefer, G., 2013. Estimating the hydrogen isotopic composition of past precipitation using leaf-waxes from western Africa. Quaternary Science Reviews 65, 88-101.

Cowling, R.M., Richardson, D.M., Pierce, S.M., 1997. Vegetation of Southern Africa. Cambridge University Press.

Dansgaard, W., 1964. Stable isotopes in precipitation. Tellus 16, 436-468. doi:10.1111/j.2153-3490.1964.tb00181.x

Dawson, T.E., 1993. Hydraulic lift and water use by plants: implications for water balance, performance and plant-plant interactions. Oecologia 95, 565-574. doi:10.1007/BF00317442

de Vries, J.J., Selaolo, E.T., Beekman, H.E., 2000. Groundwater recharge in the Kalahari, with reference to paleo-hydrologic conditions. Journal of Hydrology 238, 110-123. doi:10.1016/S0022-1694(00)00325-5

Diamond, R.E., 2014. Stable isotope hydrology of the Table Mountain group (PhD thesis). University of Cape Town.

Diefendorf, A.F., Freeman, K.H., Wing, S.L., Graham, H. V., 2011. Production of $n$-alkyl lipids in living plants and implications for the geologic past. Geochimica et Cosmochimica Acta 75, 7472-7485. doi:10.1016/j.gca.2011.09.028

Douglas, P.M.J., Pagani, M., Brenner, M., Hodell, D.A., Curtis, J.H., 2012. Aridity and vegetation composition are important determinants of leaf-wax $\delta D$ values in southeastern Mexico and Central America. Geochimica et Cosmochimica Acta 97, 24-45. doi:10.1016/j.gca.2012.09.005

Dupont, L., Wyputta, U., 2003. Reconstructing pathways of aeolian pollen transport to the marine sediments along the coastline of SW Africa. Quaternary Science Reviews 22, 157-174. doi:10.1016/S0277-3791(02)00032-X

Eckardt, F.D., Kuring, N., 2005. SeaWiFS identifies dust sources in the Namib Desert. International Journal of Remote Sensing 26, 4159-4167. doi:10.1080/01431160500113112

Eglinton, T.I., Eglinton, G., 2008. Molecular proxies for paleoclimatology. Earth and Planetary Science Letters 275, 1-16. doi:10.1016/j.epsl.2008.07.012

Ehleringer, J.R., Dawson, T.E., 1992. Water uptake by plants: perspectives from stable isotope composition. Plant, Cell and Environment 15, 1073-1082. 
Final version available at

http://www.sciencedirect.com/science/article/pii/S0146638016302273

640

641

642

643

644

645

646

647

648

649

650

651

652

653

654

655

656

657

658

659

660

661

662

663

664

665

666

667

668

669

670

671

672

673

674

675

676

677

678

679

680

681

doi:10.1111/j.1365-3040.1992.tb01657.x

Esler, K.J., Rundel, P.W., 1999. Comparative Patterns of Phenology and Growth Form Diversity in Two Winter Rainfall Deserts: The Succulent Karoo and Mojave Desert Ecosystems. Plant Ecology 142, 97-104.

Farquhar, G.D., Ehleringer, J.R., Hubick, K.T., 1989. Carbon Isotope Discrimination and Photosynthesis. Annual Review of Plant Physiology and Plant Molecular Biology 40, 503-537. doi:10.1146/annurev.pp.40.060189.002443

Feakins, S.J., Bentley, L.P., Salinas, N., Shenkin, A., Blonder, B., Goldsmith, G.R., Ponton, C., Arvin, L.J., Wu, M.S., Peters, T., West, A.J., Martin, R.E., Enquist, B.J., Asner, G.P., Malhi, Y., 2016. Plant leaf wax biomarkers capture gradients in hydrogen isotopes of precipitation from the Andes and Amazon. Geochimica et Cosmochimica Acta 182, 155-172. doi:10.1016/j.gca.2016.03.018

Feakins, S.J., Sessions, A.L., 2010a. Controls on the D/H ratios of plant leaf waxes in an arid ecosystem. Geochimica et Cosmochimica Acta 74, 2128-2141. doi:10.1016/j.gca.2010.01.016

Feakins, S.J., Sessions, A.L., 2010b. Crassulacean acid metabolism influences D/H ratio of leaf wax in succulent plants. Organic Geochemistry 41, 1269-1276.

Flanagan, L.B., Ehleringer, J.R., 1991. Stable Isotope Composition of Stem and Leaf Water: Applications to the Study of Plant Water Use. Functional Ecology 5, 270277. doi:10.2307/2389264

Gamarra, B., Sachse, D., Kahmen, A., 2016. Effects of leaf water evaporative ${ }^{2} \mathrm{H}$ enrichment and biosynthetic fractionation on leaf wax $n$-alkane $\delta^{2} \mathrm{H}$ values in $\mathrm{C} 3$ and C4 grasses. Plant, Cell \& Environment. doi:10.1111/pce.12789

Gao, L., Edwards, E.J., Zeng, Y., Huang, Y., 2014. Major evolutionary trends in hydrogen isotope fractionation of vascular plant leaf waxes. PloS ONE 9, e112610. doi:10.1371/journal.pone. 0112610

Gao, L., Guimond, J., Thomas, E., Huang, Y., 2015. Major trends in leaf wax abundance, $\delta^{2} \mathrm{H}$ and $\delta^{13} \mathrm{C}$ values along leaf venation in five species of $\mathrm{C}_{3}$ plants: Physiological and geochemical implications. Organic Geochemistry 78, 144-152. doi:10.1016/j.orggeochem.2014.11.005

Garcin, Y., Schefuß, E., Schwab, V.F., Garreta, V., Gleixner, G., Vincens, A., Todou, G., Séné, O., Onana, J.-M., Achoundong, G., Sachse, D., 2014. Reconstructing $\mathrm{C}_{3}$ and $\mathrm{C}_{4}$ vegetation cover using $n$-alkane carbon isotope ratios in recent lake sediments from Cameroon, Western Central Africa. Geochimica et Cosmochimica Acta 142, 482-500. doi:10.1016/j.gca.2014.07.004

Garcin, Y., Schwab, V.F., Gleixner, G., Kahmen, A., Todou, G., Séné, O., Onana, J.-M., Achoundong, G., Sachse, D., 2012. Hydrogen isotope ratios of lacustrine sedimentary $n$-alkanes as proxies of tropical African hydrology: Insights from a calibration transect across Cameroon. Geochimica et Cosmochimica Acta 79, 106126. doi:10.1016/j.gca.2011.11.039

Gat, J.R., 1996. Oxygen and hydrogen isotopes in the hydrologic cycle. Annual Review of Earth and Planetary Sciences 24, 225-262. doi:10.1146/annurev.earth.24.1.225 
682

683

684

685

686

687

688

689

690

691

692

693

694

695

696

697

698

699

700

701

702

703

704

705

706

707

708

709

710

711

712

713

714

715

716

717

718

719

720

721

722

723

Harris, C., Burgers, C., Miller, J., Rawoot, F., 2010. O- and H-isotope record of Cape Town rainfall from 1996 to 2008, and its application to recharge studies of Table Mountain groundwater, South Africa. South African Journal of Geology 113, 33-56. doi:10.2113/gssajg.113.1.33

Hawkins, H., Hettasch, H., West, A.G., Cramer, M.D., 2009. Hydraulic redistribution by Protea "Sylvia" (Proteaceae) facilitates soil water replenishment and water acquisition by an understorey grass and shrub. Functional Plant Biology 36, 752760.

Herrmann, N., Boom, A., Carr, A.S., Chase, B.M., Granger, R., Hahn, A., Zabel, M., Schefuß, E., 2016. Sources, transport and deposition of terrestrial organic material: A case study from southwestern Africa. Quaternary Science Reviews 149, 215-229. doi:10.1016/j.quascirev.2016.07.028

Hijmans, R.J., Cameron, S.E., Parra, J.L., Jones, P.G., Jarvis, A., 2005. Very high resolution interpolated climate surfaces for global land areas. International Journal of Climatology 25, 1965-1978. doi:10.1002/joc.1276

Holdsworth, G., Fogarasi, S., Krouse, H.R., 1991. Variation of the stable isotopes of water with altitude in the Saint Elias Mountains of Canada. Journal of Geophysical Research 96, 7483-7494. doi:10.1029/91JD00048

Hou, J., D'Andrea, W.J., Huang, Y., 2008. Can sedimentary leaf waxes record D/H ratios of continental precipitation? Field, model, and experimental assessments. Geochimica et Cosmochimica Acta 72, 3503-3517. doi:10.1016/j.gca.2008.04.030

Hou, J., D’Andrea, W.J., MacDonald, D., Huang, Y., 2007a. Evidence for water use efficiency as an important factor in determining the $\delta \mathrm{D}$ values of tree leaf waxes. Organic Geochemistry 38, 1251-1255. doi:10.1016/j.orggeochem.2007.03.011

Hou, J., D'Andrea, W.J., MacDonald, D., Huang, Y., 2007b. Hydrogen isotopic variability in leaf waxes among terrestrial and aquatic plants around Blood Pond, Massachusetts (USA). Organic Geochemistry 38, 977-984. doi:10.1016/j.orggeochem.2006.12.009

Houze, R.A., 2012. Orographic effects on precipitating clouds. Reviews of Geophysics 50, RG1001. doi:10.1029/2011RG000365

Jia, G., Wei, K., Chen, F., Peng, P., 2008. Soil $n$-alkane $\delta D$ vs. altitude gradients along Mount Gongga, China. Geochimica et Cosmochimica Acta 72, 5165-5174. doi:10.1016/j.gca.2008.08.004

Kahmen, A., Hoffmann, B., Schefuß, E., Arndt, S.K., Cernusak, L.A., West, J.B., Sachse, D., 2013a. Leaf water deuterium enrichment shapes leaf wax $n$-alkane $\delta D$ values of angiosperm plants II: Observational evidence and global implications. Geochimica et Cosmochimica Acta 111, 50-63. doi:10.1016/j.gca.2012.09.004

Kahmen, A., Schefuß, E., Sachse, D., 2013b. Leaf water deuterium enrichment shapes leaf wax $n$-alkane $\delta D$ values of angiosperm plants I: Experimental evidence and mechanistic insights. Geochimica et Cosmochimica Acta 111, 39-49. doi:10.1016/j.gca.2012.09.003

Kortelainen, N.M., Karhu, J.A., 2004. Regional and seasonal trends in the oxygen and 
724

725

726

727

728

729

730

731

732

733

734

735

736

737

738

739

740

741

742

743

744

745

746

747

748

749

750

751

752

753

754

755

756

757

758

759

760

761

762

763

764

765

hydrogen isotope ratios of Finnish groundwaters: a key for mean annual precipitation. Journal of Hydrology 285, 143-157. doi:10.1016/j.jhydrol.2003.08.014

Krull, E., Sachse, D., Mügler, I., Thiele, A., Gleixner, G., 2006. Compound-specific $\delta^{13} \mathrm{C}$ and $\delta^{2} \mathrm{H}$ analyses of plant and soil organic matter: A preliminary assessment of the effects of vegetation change on ecosystem hydrology. Soil Biology and Biochemistry 38, 3211-3221. doi:10.1016/j.soilbio.2006.04.008

Kuechler, R.R., Schefuß, E., Beckmann, B., Dupont, L., Wefer, G., 2013. NW African hydrology and vegetation during the Last Glacial cycle reflected in plant-waxspecific hydrogen and carbon isotopes. Quaternary Science Reviews 82, 56-67. doi:10.1016/j.quascirev.2013.10.013

Liu, W., Yang, H., 2008. Multiple controls for the variability of hydrogen isotopic compositions in higher plant $n$-alkanes from modern ecosystems. Global Change Biology 14, 2166-2177. doi:10.1111/j.1365-2486.2008.01608.x

Liu, W., Yang, H., Li, L., 2006. Hydrogen isotopic compositions of $n$-alkanes from terrestrial plants correlate with their ecological life forms. Oecologia 150, 330-338. doi:10.1007/s00442-006-0494-0

Luo, P., Peng, P., Gleixner, G., Zheng, Z., Pang, Z., Ding, Z., 2011. Empirical relationship between leaf wax $n$-alkane $\delta D$ and altitude in the Wuyi, Shennongjia and Tianshan Mountains, China: Implications for paleoaltimetry. Earth and Planetary Science Letters 301, 285-296. doi:10.1016/j.epsl.2010.11.012

Matimati, I., Musil, C.F., Raitt, L., February, E., 2013. Non rainfall moisture interception by dwarf succulents and their relative abundance in an inland arid South African ecosystem. Ecohydrology 6, 818-825. doi:10.1002/eco.1304

Mclnerney, F.A., Helliker, B.R., Freeman, K.H., 2011. Hydrogen isotope ratios of leaf wax $n$-alkanes in grasses are insensitive to transpiration. Geochimica et Cosmochimica Acta 75, 541-554. doi:10.1016/j.gca.2010.10.022

Mooney, H.A., Troughton, J.H., Berry, J.A., 1977. Carbon isotope ratio measurements of succulent plants in southern Africa. Oecologia 30, 295-305. doi:10.1007/BF00399762

Mucina, L., Rutherford, M., 2006. The vegetation of South Africa, Lesotho and Swaziland., in: The Vegetation of South Africa Lesotho and Sawziland. pp. 749790. doi:10.1007/s

Musekiwa, C., Majola, K., 2013. Groundwater vulnerability Map for south africa. South African Journal of Geomatics 2, 152-162.

Niedermeyer, E.M., Forrest, M., Beckmann, B., Sessions, A.L., Mulch, A., Schefuß, E., 2016. The stable hydrogen isotopic composition of sedimentary plant waxes as quantitative proxy for rainfall in the West African Sahel. Geochimica et Cosmochimica Acta 184, 55-70. doi:10.1016/j.gca.2016.03.034

Niedermeyer, E.M., Schefuß, E., Sessions, A.L., Mulitza, S., Mollenhauer, G., Schulz, M., Wefer, G., 2010. Orbital- and millennial-scale changes in the hydrologic cycle and vegetation in the western African Sahel: insights from individual plant wax $\delta D$ and $\delta^{13} \mathrm{C}$. Quaternary Science Reviews 29, 2996-3005. 
Final version available at

http://www.sciencedirect.com/science/article/pii/S0146638016302273

766

767

768

769

770

771

772

773

774

775

776

777

778

779

780

781

782

783

784

785

786

787

788

789

790

791

792

793

794

795

796

797

798

799

800

801

802

803

804

805

806

807

doi:10.1016/j.quascirev.2010.06.039

Polissar, P.J., Freeman, K.H., 2010. Effects of aridity and vegetation on plant-wax $\delta D$ in modern lake sediments. Geochimica et Cosmochimica Acta 74, 5785-5797. doi:10.1016/j.gca.2010.06.018

Prospero, J.M., Ginoux, P., Torres, O., Nicholson, S.E., Gill, T.E., 2002. Environmental characterization of global sources of atmospheric soil dust identified with the NIMBUS 7 Total Ozone Mapping Spectrometer (TOMS) absorbing aerosol product. Reviews of Geophysics 40, 1002. doi:10.1029/2000RG000095

Rao, Z., Zhu, Z., Jia, G., Henderson, A.C.G., Xue, Q., Wang, S., 2009. Compound specific $\delta D$ values of long chain $n$-alkanes derived from terrestrial higher plants are indicative of the $\delta D$ of meteoric waters: Evidence from surface soils in eastern China. Organic Geochemistry 40, 922-930. doi:10.1016/j.orggeochem.2009.04.011

Risi, C., Bony, S., Vimeux, F., 2008. Influence of convective processes on the isotopic composition $\left(\delta^{18} \mathrm{O}\right.$ and $\left.\delta \mathrm{D}\right)$ of precipitation and water vapor in the tropics: 2 . Physical interpretation of the amount effect. Journal of Geophysical Research Atmospheres 113. doi:10.1029/2008JD009943

Rozanski, K., 1985. Deuterium and ${ }^{18} \mathrm{O}$ in European groundwaters - Links to atmospheric circulation in the past. Chemical Geology: Isotope Geoscience section 52, 349-363. doi:10.1016/0168-9622(85)90045-4

Rozanski, K., Araguás-Araguás, L., Gonfiantini, R., 1993. Isotopic Patterns in Modern Global Precipitation. Climate Change in Continental Isotopic Records 78, 1-36. doi:10.1029/GM078p0001

Rundel, P.W., Dillon, M.O., Palma, B., Mooney, H.A., Gulmon, S.L., Ehleringer, J.R., 1991. The phytogeography and ecology of the coastal Atacama and Peruvian deserts. Aliso.

Rundel, P.W., Esler, K.J., Cowling, R.M., 1999. Ecological and Phylogenetic Patterns of Carbon Isotope Discrimination in the Winter-Rainfall Flora of the Richtersveld, South Africa. Plant Ecology 142, 133-148.

Sachse, D., Billault, I., Bowen, G.J., Chikaraishi, Y., Dawson, T.E., Feakins, S.J., Freeman, K.H., Magill, C.R., McInerney, F. a., van der Meer, M.T.J., Polissar, P., Robins, R.J., Sachs, J.P., Schmidt, H.-L., Sessions, A.L., White, J.W.C., West, J.B., Kahmen, A., 2012. Molecular Paleohydrology: Interpreting the Hydrogen-Isotopic Composition of Lipid Biomarkers from Photosynthesizing Organisms. Annual Review of Earth and Planetary Sciences 40, 221-249. doi:10.1146/annurev-earth042711-105535

Sachse, D., Radke, J., Gleixner, G., 2006. $\delta D$ values of individual $n$-alkanes from terrestrial plants along a climatic gradient - Implications for the sedimentary biomarker record. Organic Geochemistry 37, 469-483. doi:10.1016/j.orggeochem.2005.12.003

Sachse, D., Radke, J., Gleixner, G., 2004. Hydrogen isotope ratios of recent lacustrine sedimentary $n$-alkanes record modern climate variability. Geochimica et Cosmochimica Acta 68, 4877-4889. doi:10.1016/j.gca.2004.06.004 
808

809

810

811

812

813

814

815

816

817

818

819

820

821

822

823

824

825

826

827

828

829

830

831

832

833

834

835

836

837

838

839

840

841

842

843

844

845

846

847

848

849

Schefuß, E., Schouten, S., Schneider, R.R., 2005. Climatic controls on central African hydrology during the past 20,000 years. Nature 437, 1003-1006.

Schimmelmann, A., Sessions, A.L., Mastalerz, M., 2006. Hydrogen isotopic (D/H) composition of organic matter during diagenesis and thermal maturation. Annual Review of Earth and Planetary Sciences 34, 501-533. doi:10.1146/annurev.earth.34.031405.125011

Schulze, E.-D., Mooney, H.A., Sala, O.E., Jobbagy, E., Buchmann, N., Bauer, G., Canadell, J., Jackson, R.B., Loreti, J., Oesterheld, M., Ehleringer, J.R., 1996. Rooting depth, water availability, and vegetation cover along an aridity gradient in Patagonia. Oecologia 108, 503-511. doi:10.1007/BF00333727

Schwab, V.F., Garcin, Y., Sachse, D., Todou, G., Séné, O., Onana, J.-M., Achoundong, G., Gleixner, G., 2015. Effect of aridity on $\delta^{13} \mathrm{C}$ and $\delta \mathrm{D}$ values of $\mathrm{C}_{3}$ plant- and $\mathrm{C}_{4}$ graminoid-derived leaf wax lipids from soils along an environmental gradient in Cameroon (Western Central Africa). Organic Geochemistry 78, 99-109. doi:10.1016/j.orggeochem.2014.09.007

Scott, L., Neumann, F.H., Brook, G.A., Bousman, C.B., Norström, E., Metwally, A.A., 2012. Terrestrial fossil-pollen evidence of climate change during the last 26 thousand years in Southern Africa. Quaternary Science Reviews 32, 100-118. doi:10.1016/j.quascirev.2011.11.010

Scott, L., Vogel, J.C., 2000. Evidence for environmental conditions during the last 20000 years in Southern Africa from $13 \mathrm{C}$ in fossil hyrax dung. Global and Planetary Change 26, 207-215.

Seki, O., Meyers, P.A., Kawamura, K., Zheng, Y., Zhou, W., 2009. Hydrogen isotopic ratios of plant wax $n$-alkanes in a peat bog deposited in northeast China during the last 16kyr. Organic Geochemistry 40, 671-677. doi:10.1016/j.orggeochem.2009.03.007

Seki, O., Nakatsuka, T., Shibata, H., Kawamura, K., 2010. A compound-specific nalkane $\delta^{13} \mathrm{C}$ and $\delta \mathrm{D}$ approach for assessing source and delivery processes of terrestrial organic matter within a forested watershed in northern Japan. Geochimica et Cosmochimica Acta 74, 599-613. doi:10.1016/j.gca.2009.10.025

Shiponeni, N., Allsopp, N., Carrick, P.J., Hoffman, M.T., 2011. Competitive interactions between grass and succulent shrubs at the ecotone between an arid grassland and succulent shrubland in the Karoo. Plant Ecology 212, 795-808. doi:10.1007/s11258-010-9864-0

Smith, F.A., Freeman, K.H., 2006. Influence of physiology and climate on $\delta D$ of leaf wax $n$-alkanes from $\mathrm{C}_{3}$ and $\mathrm{C}_{4}$ grasses. Geochimica et Cosmochimica Acta 70, 11721187. doi:10.1016/j.gca.2005.11.006

Soderberg, K.S., 2010. The role of fog in the ecohydrology and biogeochemistry of the Namib Desert.

Still, C.J., Powell, R.L., 2010. Continental-scale distributions of vegetation stable carbon isotope ratios, in: Isoscapes: Understanding Movement, Pattern, and Process on Earth through Isotope Mapping. pp. 179-193. doi:10.1007/978-90-481-3354-3_9 
850

851

852

853

854

855

856

857

858

859

860

861

862

863

864

865

866

867

868

869

870

871

872

873

874

875

876

877

878

879

880

881

882

883

884

885

886

887

888

889

890

891

Ting, I.P., 1985. Crassulacean acid metabolism. Annual Review of Plant Physiology 36, 595-622.

Trabucco, A., Zomer, R.J., 2009. Global Aridity Index (Global-Aridity) and Global Potential Evapo-Transpiration (Global-PET) Geospatial Database. CGIAR Consortium for Spatial Information. Published online, available from the CGIAR-CSI GeoPortal at: http://www.csi.cgiar.org/.

Tuthorn, M., Zech, R., Ruppenthal, M., Oelmann, Y., Kahmen, A., del Valle, H.F., Eglinton, T., Rozanski, K., Zech, M., 2015. Coupling $\delta^{2} \mathrm{H}$ and $\delta^{18} \mathrm{O}$ biomarker results yields information on relative humidity and isotopic composition of precipitation - a climate transect validation study. Biogeosciences 12, 3913-3924. doi:10.5194/bg12-3913-2015

Tyson, P.D., 1986. Climatic change and variability in southern Africa. Oxford University Press, Cape Town; New York.

Tyson, P.D., Preston-Whyte, R.A., 2000. The Weather and Climate of Southern Africa. Oxford University Press Southern Africa.

Vickery, K.J., Eckardt, F.D., Bryant, R.G., 2013. A sub-basin scale dust plume source frequency inventory for southern Africa, 2005-2008. Geophysical Research Letters 40, 5274-5279.

Vogel, J.C., 1978. Recycling of carbon in a forest environment. Oecologia Plantarum 13, 89-94.

Wassenaar, L.I., Van Wilgenburg, S.L., Larson, K., Hobson, K.A., 2009. A groundwater isoscape $\left(\delta \mathrm{D}, \delta^{18} \mathrm{O}\right)$ for Mexico. Journal of Geochemical Exploration 102, 123-136. doi:10.1016/j.gexplo.2009.01.001

Werger, M.J.A., Ellis, R.P., 1981. Photosynthetic pathways in the arid regions of South Africa. Flora 171, 64-75.

West, A.G., Dawson, T.E., February, E.C., Midgley, G.F., Bond, W.J., Aston, T.L., 2012. Diverse functional responses to drought in a Mediterranean-type shrubland in South Africa. New Phytologist 195, 396-407. doi:10.1111/j.1469-8137.2012.04170.x

West, A.G., February, E.C., Bowen, G.J., 2014. Spatial analysis of hydrogen and oxygen stable isotopes ("isoscapes") in ground water and tap water across South Africa. Journal of Geochemical Exploration 145, 213-222. doi:10.1016/j.gexplo.2014.06.009

Worden, J., Noone, D., Bowman, K., 2007. Importance of rain evaporation and continental convection in the tropical water cycle. Nature 445, 528-32. doi:10.1038/nature05508

Zech, M., Zech, R., Rozanski, K., Gleixner, G., Zech, W., 2015. Do n-alkane biomarkers in soils/sediments reflect the $\delta^{2} \mathrm{H}$ isotopic composition of precipitation? A case study from Mt. Kilimanjaro and implications for paleoaltimetry and paleoclimate research. Isotopes in Environmental and Health Studies 1-17. doi:10.1080/10256016.2015.1058790

Zhou, Y., Grice, K., Chikaraishi, Y., Stuart-Williams, H., Farquhar, G.D., Ohkouchi, N., 2011. Temperature effect on leaf water deuterium enrichment and isotopic 
Final version available at

http://www.sciencedirect.com/science/article/pii/S0146638016302273

892 fractionation during leaf lipid biosynthesis: Results from controlled growth of $\mathrm{C}_{3}$ and $893 \quad \mathrm{C}_{4}$ land plants. Phytochemistry 72, 207-213. doi:10.1016/j.phytochem.2010.10.022

894 


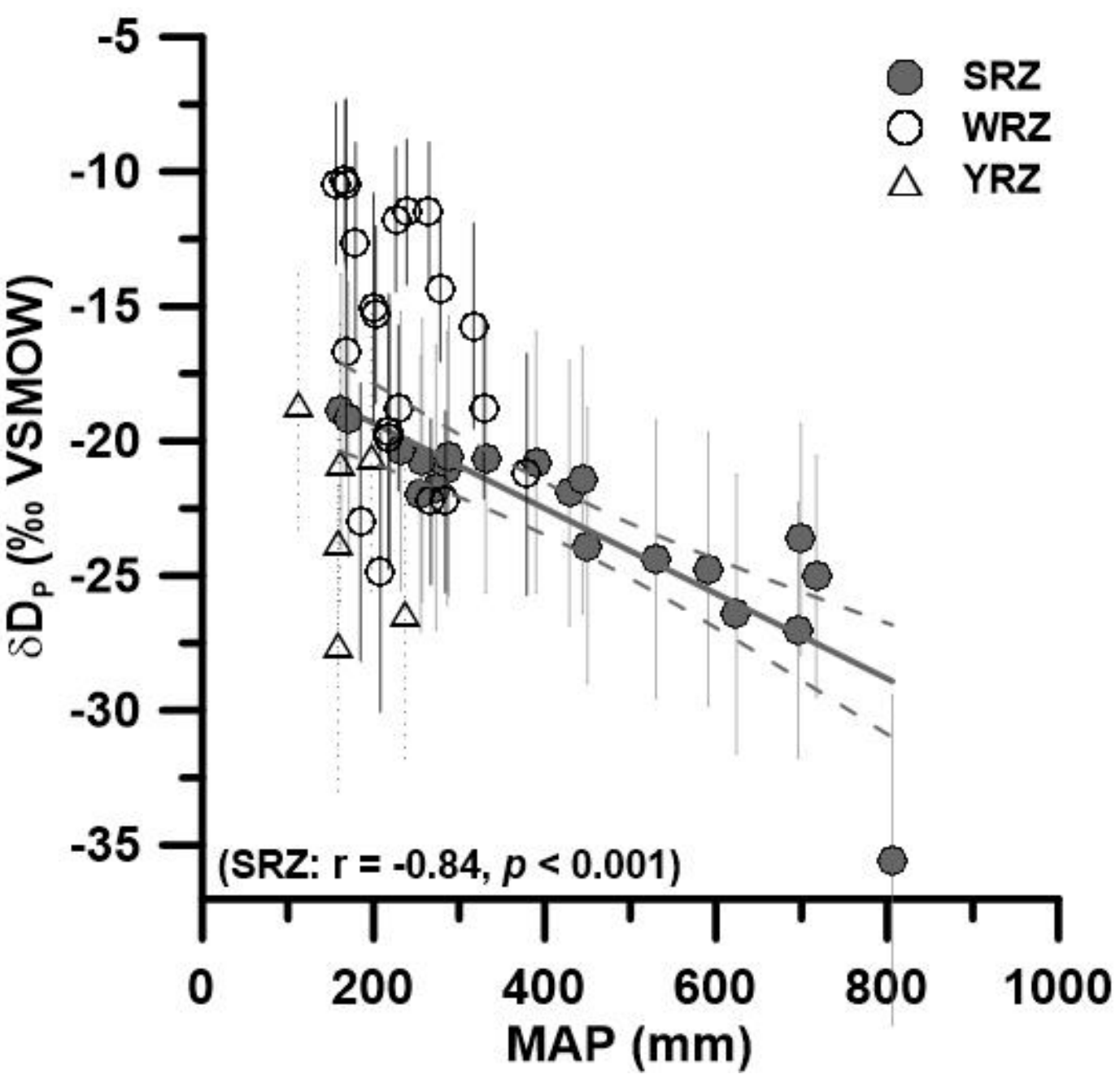

897 Fig. 2. Comparison of mean annual precipitation (MAP; Hijmans et al., 2005) and interpolated $\delta \mathrm{D}$ values 898 of annual precipitation (OIPC; Bowen and Revenaugh, 2003) for the locations in the study area. The 899 locations are divided into the summer rainfall (SRZ, closed grey dots), winter rainfall (WRZ, open dots) 900 and year round rainfall (YRZ, open triangles) zones. Grey line indicates the linear fit for the SRZ data and 901 dashed lines indicate the $95 \%$ confidence interval. 

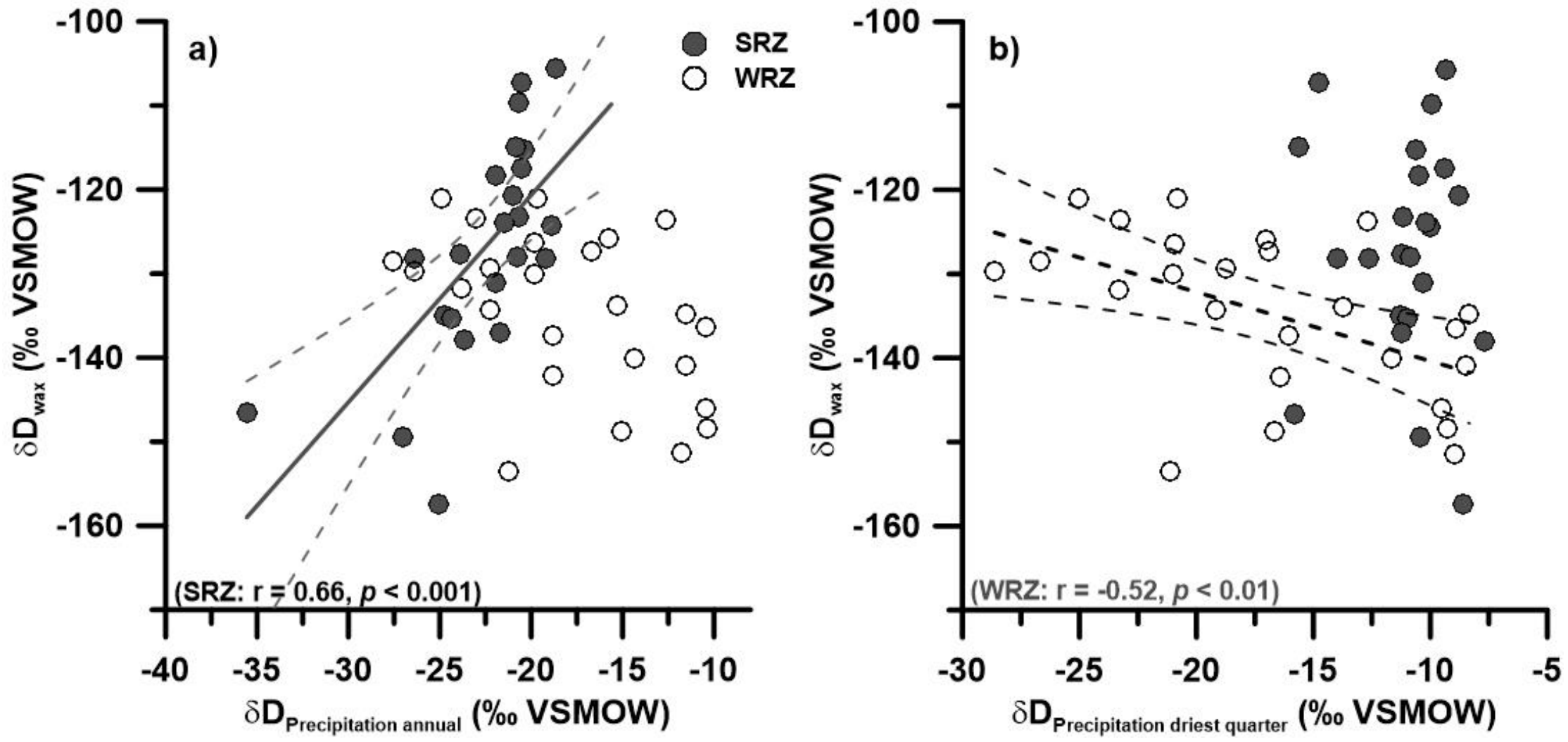

904 Fig. 3.Comparison of compound-specific $\delta D_{w a x}$ (amount weighted mean of $C_{29}$ and $C_{31}$ ) and $\delta D$ of annual precipitation (left) as well as $\delta D_{w a x}$ and $\delta D$ of 905 the driest quarter (right) for the soil samples. The locations of the soils are divided into summer rainfall (SRZ, closed grey dots) and winter rainfall 906 (WRZ, open dots) zones in (a,b). The grey line in a) line shows the linear fit in the SRZ and the black dashed line in b) shows the linear fit in the WRZ. 907 Dashed lines around the linear fits indicate the 95\% confidence interval. Isotope data for precipitation are from OIPC (Bowen and Revenaugh, 2003). 

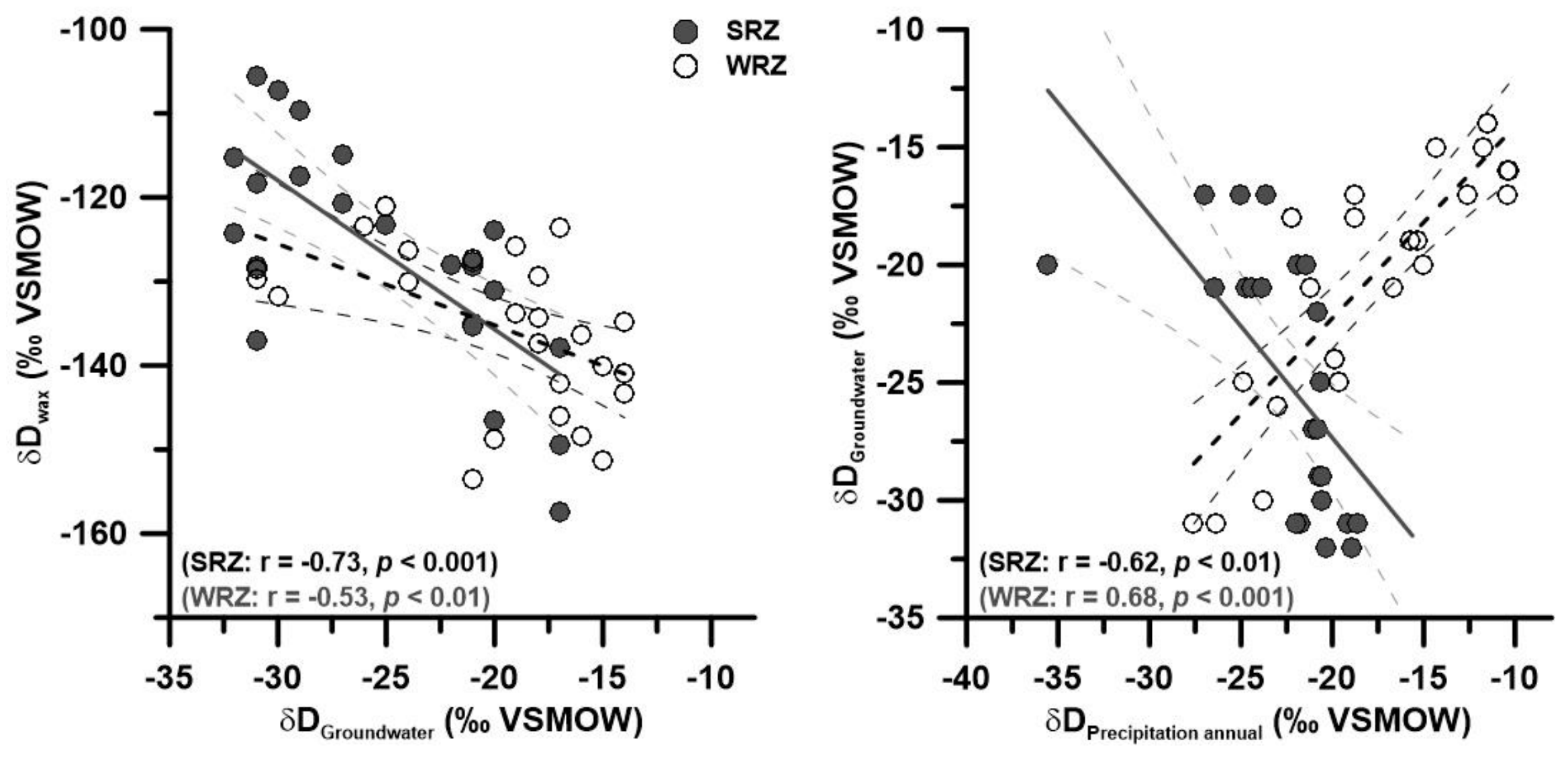

909 Fig. 4. Comparison of compound-specific $\delta D_{\text {wax }}$ (amount weighted mean of $C_{29}$ and $C_{31}$ ) and interpolated $\delta D$ of groundwater (left, West et al., 2014) as

910 well as $\delta \mathrm{D}$ values of groundwater and annual precipitation (right, Bowen and Revenaugh, 2003) for the locations of the soil samples. The locations are

911 divided into summer rainfall (SRZ, closed grey dots) and winter rainfall zones (WRZ, open dots). Linear fits and 95\% confidence intervals are shown

912 for both rainfall zones. Thick grey lines are the linear fits for the SRZ and thick dashed lines are the linear fits for the WRZ. 


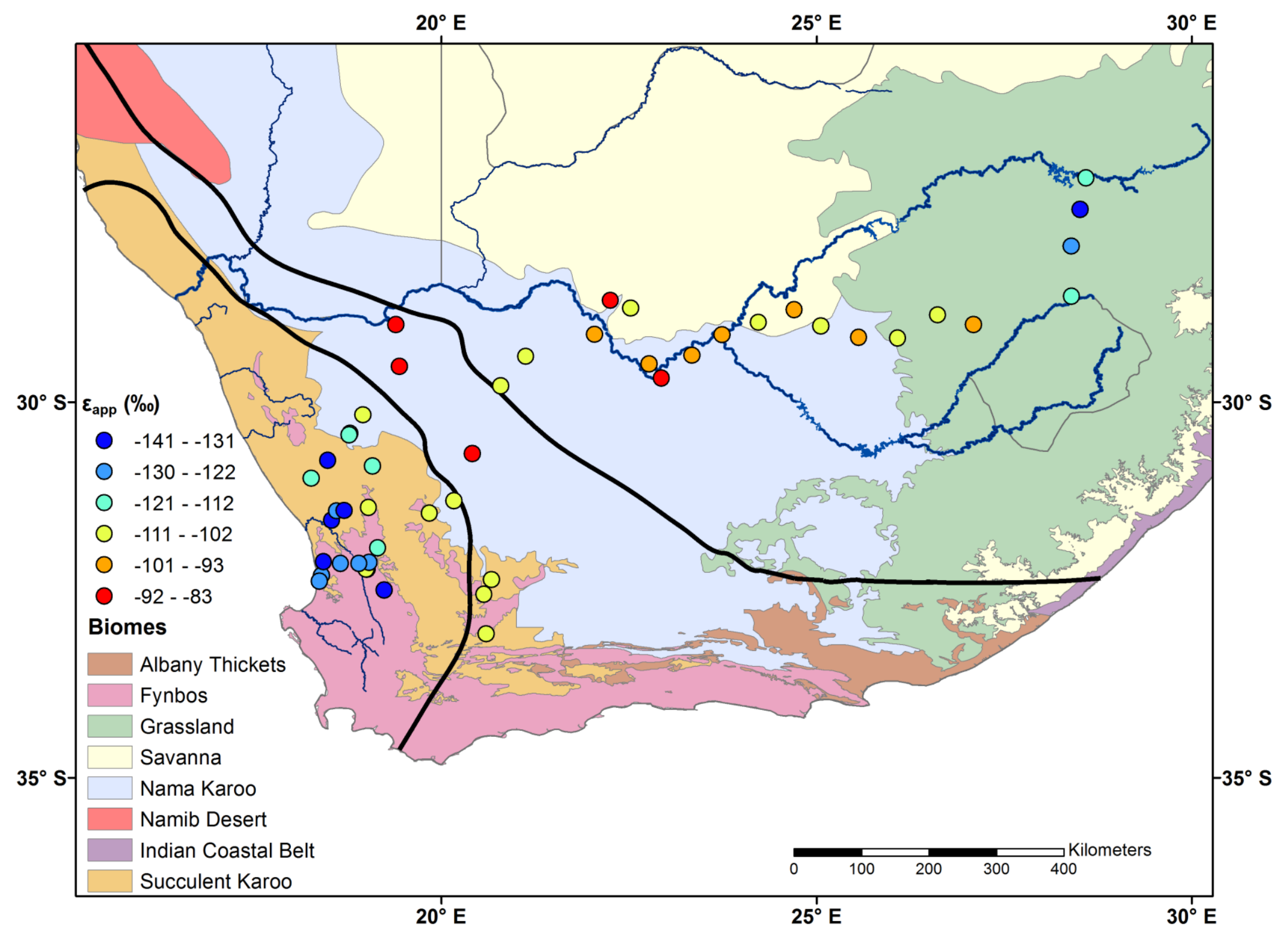

Fig. 5. Amount weighted mean apparent hydrogen isotope fractionation $\left(\varepsilon_{\text {app }}\right)$ values of plant wax alkanes in the study area with modern biomes (after Mucina and Rutherford, 2006; Scott et al., 2012). Boundaries of the main rainfall zones are indicated with black lines. 

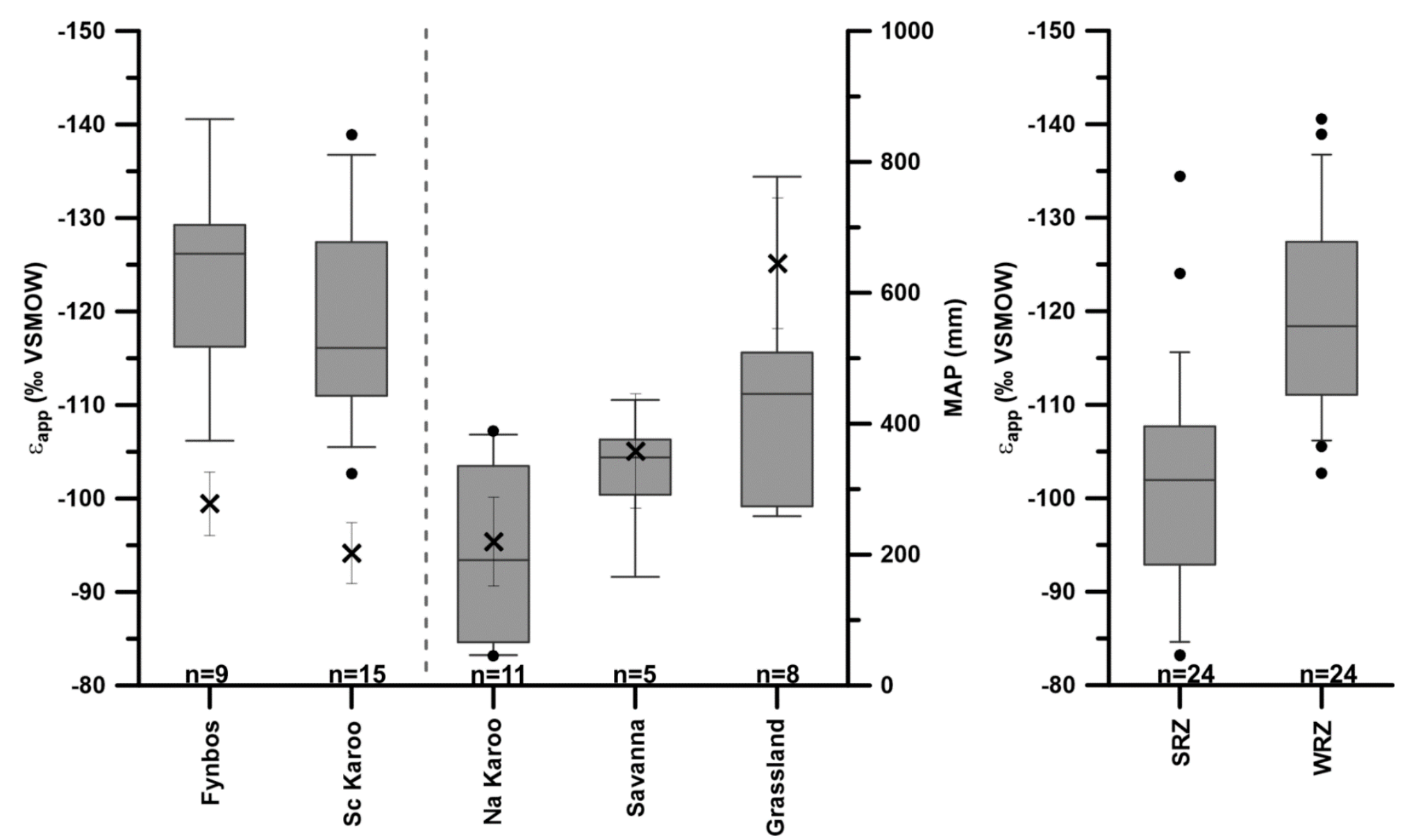

915 Fig. 6. Box and whisker plots for the apparent hydrogen isotope fractionation ( $\left.\varepsilon_{\text {app }}\right)$ of plant wax derived $n$-alkanes in soils from different biomes (left) 916 and rainfall zones (right). Boxes comprise middle $50 \%$ of samples and the horizontal black line within the box represents the median. Black dots 917 outside the whisker plots indicate the uppermost and lowermost 10\%. Na Karoo and Sc Karoo indicate Nama Karoo and Succulent Karoo, 918 respectively. Black crosses indicate the mean of mean annual precipitation (MAP) for each biome. Vertical dashed grey line separates WRZ 919 dominated biomes (Fynbos, Sc Karoo) from SRZ dominated biomes (Na Karoo, Savanna, Grassland). Note that Eapp is shown on an inverse axis. 

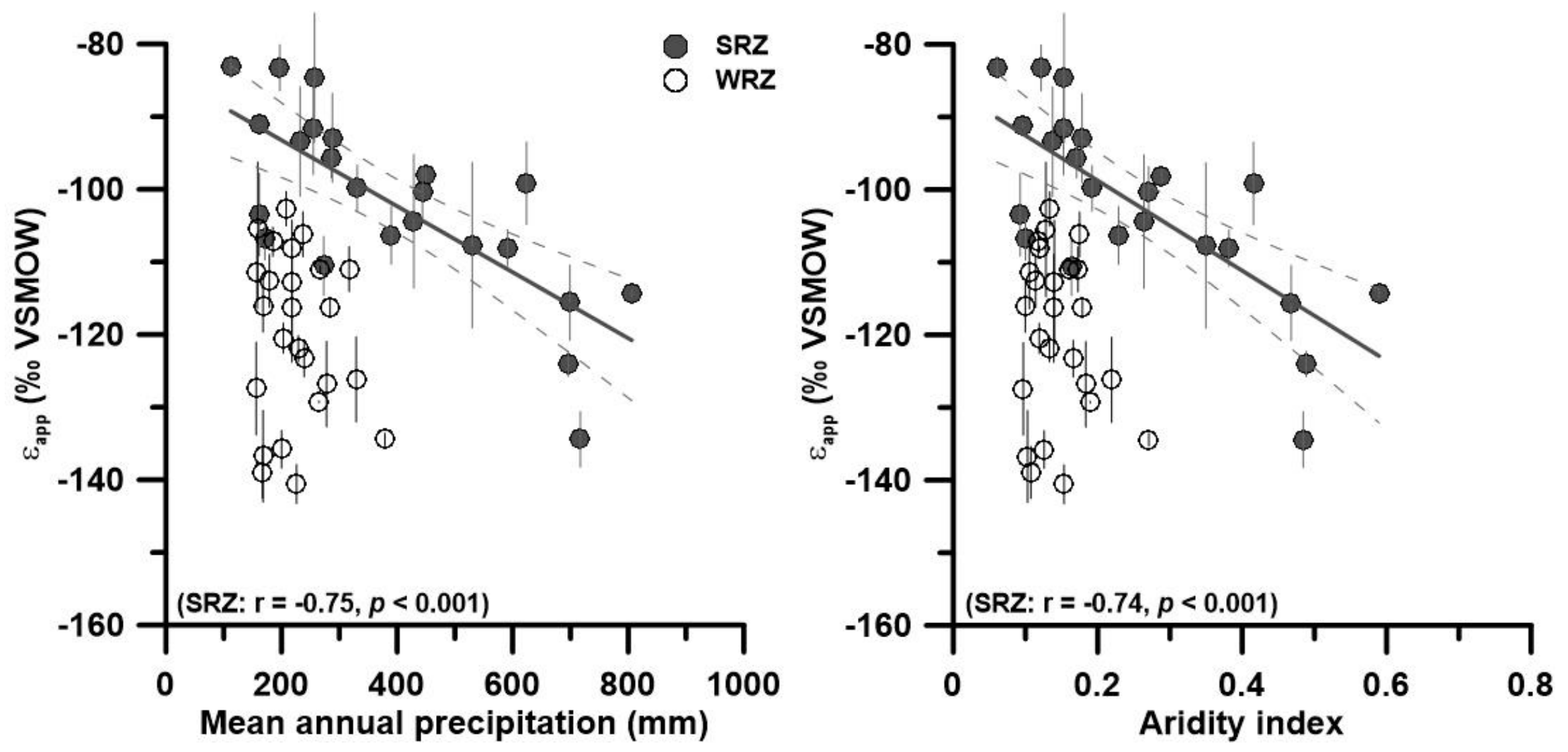

921 Fig. 7. Correlation of apparent hydrogen isotope fractionation ( $\left.\varepsilon_{\text {app }}\right)$ with mean annual precipitation (left, Hijmans et al., 2005) and aridity index (right, 922 Trabucco and Zomer, 2009) in South Africa divided into the summer rainfall (SRZ, grey dots) and winter rainfall zone (WRZ, open dots). Grey lines 923 show linear fits and grey dashed lines $95 \%$ confidence intervals of the SRZ samples. 

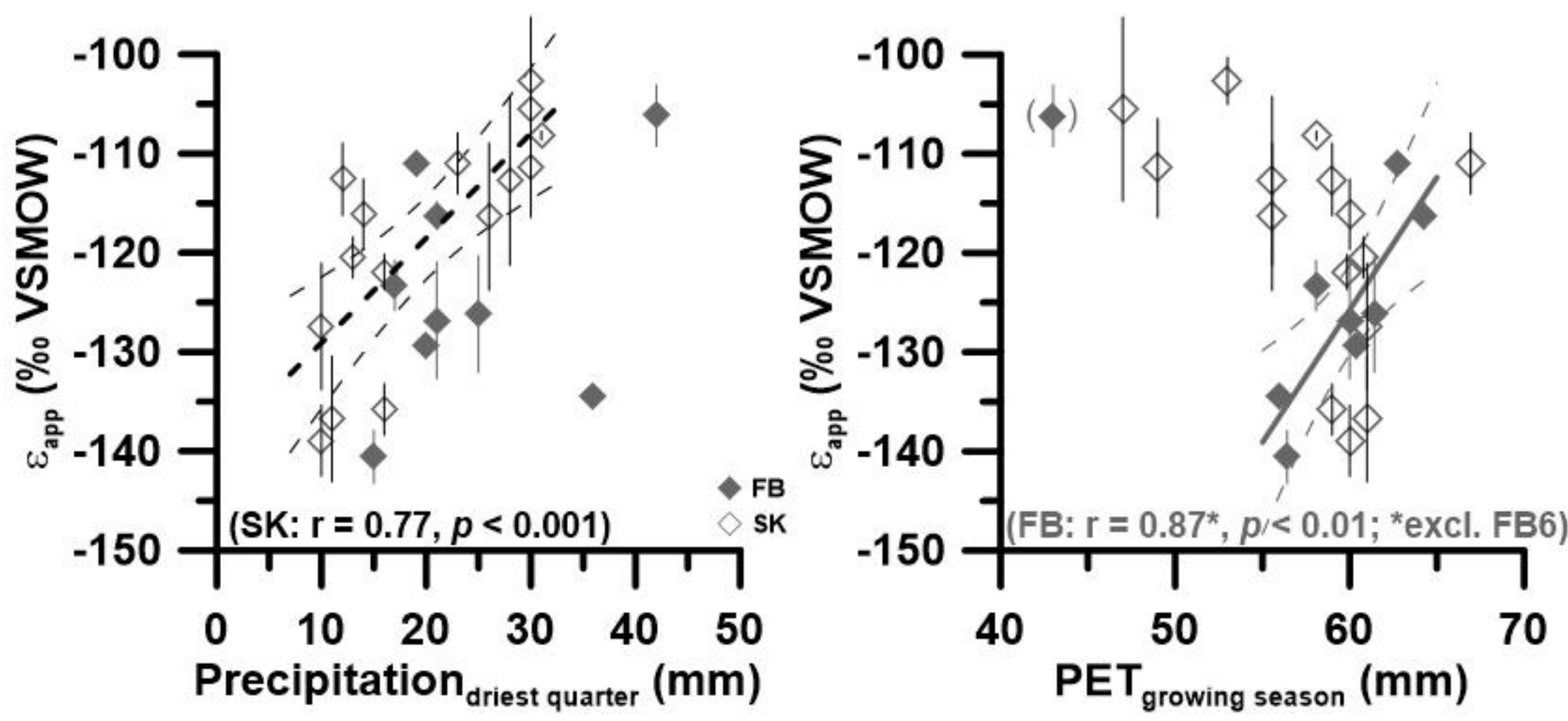

925 Fig. 8. Correlation of apparent hydrogen isotope fractionation ( $\left.\varepsilon_{\text {app }}\right)$ with driest quarter precipitation (left) and growing season potential

926 evapotranspiration (PET, right) in the WRZ divided into the Succulent Karoo (SK, grey open diamonds) and Fynbos (FB, grey diamonds) biomes. An

927 outlier was excluded for the Pearson correlation coefficient between $\varepsilon_{\text {app }}$ and PET of Fynbos soils. Linear fits and $95 \%$ confidence intervals are shown

928 for SK soils (left) and FB soils (right), respectively. 


\section{Table 1}

$931 \delta \mathrm{D}$ values (minimum, maximum and range) of precipitation, individual $n$-alkanes $\left(\mathrm{C}_{29}, \mathrm{C}_{31}\right)$ and amount weighted mean of $n$-alkanes $\left(\mathrm{C}_{29}\right.$ and $\left.\mathrm{C}_{31}\right)$ in 932 the study area separated into different rainfall zones and biomes.

\begin{tabular}{|c|c|c|c|c|c|c|c|c|c|c|c|c|}
\hline & \multicolumn{3}{|c|}{$\begin{array}{l}\delta D_{p}(\% o) \\
\text { annual (OIPC) }\end{array}$} & \multicolumn{3}{|c|}{$\delta D_{c 29}(\% 0)$} & \multicolumn{3}{|l|}{$\delta D_{c 31}(\%)$} & \multicolumn{3}{|c|}{$\begin{array}{l}\delta \mathrm{D}_{\text {wax }}(\%) \text { weighted mean } \\
\left(\mathrm{C}_{29}+\mathrm{C}_{31}\right)\end{array}$} \\
\hline & $\min$ & $\max$ & range & $\min$ & $\max$ & range & $\min$ & $\max$ & range & $\min$ & $\max$ & range \\
\hline \multicolumn{13}{|l|}{ Rainfall zone } \\
\hline $\operatorname{SRZ}(n=21)$ & -36 & -19 & 17 & $-151 \pm 0$ & $-75 \pm 0$ & 76 & $-161 \pm 1$ & $-111 \pm 1$ & 49 & $-157 \pm 4$ & $-108 \pm 8$ & 49 \\
\hline WRZ $(n=21)$ & -25 & -10 & 15 & $-146 \pm 1$ & $-82 \pm 0$ & 64 & $-163 \pm 1$ & $-120 \pm 1$ & 44 & $-163 \pm 1$ & $-120 \pm 4$ & 33 \\
\hline YRZ (n=6) & -28 & -19 & 9 & $-136 \pm 1$ & $-83 \pm 2$ & 53 & $-135 \pm 1$ & $-105 \pm 1$ & 30 & $-132 \pm 5$ & $-106 \pm 1$ & 26 \\
\hline \multicolumn{13}{|l|}{ Biome } \\
\hline Fynbos $(n=9)$ & -24 & -6 & 18 & $-146 \pm 1$ & $-121 \pm 1$ & 25 & $-163 \pm 1$ & $-125 \pm 0$ & 38 & $-163 \pm 1$ & $-125 \pm 1$ & 38 \\
\hline Succulent Karoo $(n=15)$ & -23 & -5 & 18 & $-142 \pm 1$ & $-82 \pm 0$ & 60 & $-156 \pm 0$ & $-120 \pm 1$ & 36 & $-154 \pm 4$ & $-121 \pm 2$ & 33 \\
\hline Nama Karoo $(n=11)$ & -17 & -10 & -7 & $-117 \pm 1$ & $-75 \pm 0$ & 42 & $-134 \pm 1$ & $-105 \pm 1$ & 29 & $-133 \pm 3$ & $-106 \pm 1$ & 27 \\
\hline Savanna $(n=5)$ & -16 & -14 & 2 & $-119 \pm 0$ & $-103 \pm 3$ & 16 & $-141 \pm 1$ & $-123 \pm 1$ & 18 & $-141 \pm 2$ & $-118 \pm 6$ & 23 \\
\hline Grassland $(\mathrm{n}=8)$ & -31 & -18 & 13 & $-151 \pm 0$ & $-112 \pm 2$ & 39 & $-161 \pm 1$ & $-129 \pm 1$ & 32 & $-157 \pm 4$ & $-128 \pm 1$ & 29 \\
\hline
\end{tabular}


Final version available at

http://www.sciencedirect.com/science/article/pii/S0146638016302273

934

Table 2

935 Pearson correlation coefficients $(r)$ between $\delta D_{\text {wax }}$ and $\delta D_{p}$ values of annual precipitation and precipitation

936 during the driest quarter for the different rainfall zones and biomes.

\begin{tabular}{|c|c|c|}
\hline$\delta D_{\text {wax }}$ & $\begin{array}{c}\delta D_{p} \text { annual } \\
(\% \circ \text { VSMOW })\end{array}$ & $\begin{array}{c}\delta \mathrm{D}_{\mathrm{p}} \text { driest } \\
\text { quarter (\%o VSMOW) }\end{array}$ \\
\hline All $(n=48)$ & $r=-0.12, p=0.41$ & $r=-0.09, p=0.55$ \\
\hline$S R Z(n=21)$ & $r=0.65, p<0.01$ & $r=0.12, p=0.62$ \\
\hline WRZ (n=21) & $r=-0.48, p=0.02$ & $r=-0.48, p=0.03$ \\
\hline YRZ $(n=6)$ & $r=0.82, p=0.04$ & $r=0.93, p<0.01$ \\
\hline $\operatorname{SRZ/YRZa}(n=24)$ & $r=0.66, p<0.001$ & $r=0.09, p=0.68$ \\
\hline WRZ/YRZb $(n=24)$ & $r=-0.48, p=0.02$ & $r=-0.52, p<0.01$ \\
\hline Fynbos $(n=9)$ & $r=-0.42, p=0.26$ & $r=-0.33, p=0.38$ \\
\hline Sc Karoo ${ }^{c}(n=15)$ & $r=-0.58, p=0.03$ & $r=-0.60, p=0.02$ \\
\hline Na Karood $(n=11)$ & $r=0.02, p=0.95$ & $r=0.22, p=0.51$ \\
\hline Savanna $(n=5)$ & $r=0.22, p=0.73$ & $r=0.02, p=0.97$ \\
\hline Grassland $(n=8)$ & $r=0.34, p=0.40$ & $r=-0.16, p=0.71$ \\
\hline
\end{tabular}

937 a For $\delta D_{\text {wax }}$ SRZ/YRZ the locations CNT5, CNT6 and GTC30 (see Supplementary materials) from the 938 northern parts of the YRZ are included;

$939 \mathrm{~b}$ for $\delta D_{\text {wax }}$ WRZ/YRZ the locations FB6, SK11, SK12 and NK1 (see Supplementary materials) from the 940 southern parts of the YRZ are included;

941 c Succulent Karoo;

942 d Nama Karoo.

943 


\section{Table 3}

945 Pearson correlation coefficient ( $r$ ) between $\varepsilon_{\text {app }}$ and $\delta^{13} C_{\text {wax }}$ as well as different environmental parameters for the rainfall zones (SRZ, summer rainfall

946 zone; WRZ, winter rainfall zone) and the individual biomes. Bold numbers represent significant correlation coefficients (Sc Karoo, Succulent Karoo; Na

947 Karoo, Nama Karoo; gs, growing season; qu, quarter).

\begin{tabular}{|c|c|c|c|c|c|c|c|c|c|c|c|c|c|c|}
\hline & \multicolumn{2}{|c|}{$\varepsilon_{\text {app }} \mathrm{SRZ}$} & \multicolumn{2}{|c|}{$\varepsilon_{\text {app }}$ WRZ } & \multicolumn{2}{|c|}{$\varepsilon_{\text {app }}$ Sc Karoo } & \multicolumn{2}{|c|}{$\varepsilon_{\text {app }}$ Fynbos } & \multicolumn{2}{|c|}{$\varepsilon_{\text {app }} \mathrm{Na}$ Karoo } & \multicolumn{2}{|c|}{$\varepsilon_{\text {app }}$ Savanna } & \multicolumn{2}{|c|}{$\varepsilon_{\text {app }}$ Grassland } \\
\hline & $r$ & $p$ & $r$ & $p$ & $r$ & $p$ & $r$ & $p$ & $r$ & $p$ & $r$ & $p$ & $r$ & $p$ \\
\hline$\delta^{13} \mathrm{C}_{\mathrm{wax}}$ & -0.24 & 0.264 & 0.27 & 0.211 & 0.11 & 0.704 & 0.28 & 0.470 & 0.49 & 0.124 & -0.22 & 0.729 & -0.39 & 0.337 \\
\hline MAP & -0.75 & $<0.001$ & -0.12 & 0.540 & 0.28 & 0.322 & -0.24 & 0.535 & -0.07 & 0.84 & -0.14 & 0.818 & -0.66 & 0.074 \\
\hline Precip. gs & -0.75 & $<0.001$ & -0.24 & 0.247 & 0.14 & 0.620 & -0.33 & 0.382 & -0.12 & 0.729 & 0.15 & 0.810 & -0.73 & 0.04 \\
\hline MAT & 0.68 & $<0.001$ & -0.46 & 0.020 & -0.69 & $<0.01$ & -0.35 & 0.351 & 0.31 & 0.364 & 0.34 & 0.579 & 0.60 & 0.112 \\
\hline Aridity index & -0.74 & $<0.001$ & -0.17 & 0.407 & 0.40 & 0.136 & -0.31 & 0.423 & -0.07 & 0.833 & -0.13 & 0.839 & -0.63 & 0.097 \\
\hline Altitude & -0.51 & 0.300 & 0.62 & $<0.001$ & $-0,69$ & $<0.01$ & 0.42 & 0.262 & -0.12 & 0.732 & -0.25 & 0.686 & -0.54 & 0.165 \\
\hline PET annual & 0.64 & $<0.01$ & 0.07 & 0.744 & -0.33 & 0.23 & 0.26 & 0.495 & -0.17 & 0.625 & 0.00 & 0.996 & 0.46 & 0.257 \\
\hline PET gs & -0.11 & 0.622 & -0.37 & 0.066 & -0.46 & 0.089 & $0.87^{a}$ & $<0.01^{a}$ & 0.46 & 0.151 & -0.23 & 0.709 & -0.66 & 0.07 \\
\hline \multicolumn{15}{|c|}{ Precipitation } \\
\hline Driest qu. & -0.55 & $<0.01$ & 0.56 & $<0.01$ & 0.77 & $<0.001$ & 0.36 & 0.344 & -0.19 & 0.576 & -0.14 & 0.819 & -0.13 & 0.759 \\
\hline Wettest qu. & -0.75 & $<0.001$ & -0.38 & 0.058 & -0.18 & 0.515 & -0.43 & 0.250 & -0.05 & 0.881 & -0.15 & 0.814 & -0.68 & 0.063 \\
\hline Warmest qu. & -0.76 & $<0.001$ & 0.53 & $<0.01$ & 0.69 & $<0.01$ & 0.31 & 0.424 & -0.03 & 0.936 & -0.15 & 0.816 & -0.67 & 0.068 \\
\hline Seasonality & 0.23 & 0.290 & -0.67 & $<0.001$ & -0.67 & $<0.01$ & -0.51 & 0.160 & 0.12 & 0.715 & -0.04 & 0.950 & -0.60 & 0.118 \\
\hline \multicolumn{15}{|c|}{ Temperature } \\
\hline Annual range & 0.49 & 0.018 & 0.69 & $<0.001$ & 0.64 & 0.01 & 0.71 & 0.033 & -0.18 & 0.605 & -0.29 & 0.635 & 0.42 & 0.297 \\
\hline $\begin{array}{l}\text { Min. coldest } \\
\text { month }\end{array}$ & 0.74 & $<0.001$ & -0.66 & $<0.001$ & -0.74 & $<0.01$ & -0.55 & 0.122 & 0.41 & 0.213 & 0.31 & 0.616 & 0.68 & 0.063 \\
\hline
\end{tabular}


Final version available at http://www.sciencedirect.com/science/article/pii/S0146638016302273

Max. warmest

$0.72<0.001$

$\begin{array}{llll}0.05 & 0.813 & -0.28 & 0.313\end{array}$

0.21

0.592

$0.24 \quad 0.482$

0.07

0.906

$0.67 \quad 0.071$

a Excluding location FB6 improved the correlation for "PET gs", with location FB6: $r-0.23, p 0.56$. 